\title{
Wastewater Treatment and Reuse: a Review of its Applications and Health Implications
}

\author{
Kavindra Kumar Kesari $(\mathbb{D} \cdot$ Ramendra Soni • Qazi Mohammad Sajid Jamal • Pooja \\ Tripathi • Jonathan A. Lal • Niraj Kumar Jha • Mohammed Haris Siddiqui • Pradeep \\ Kumar • Vijay Tripathi • Janne Ruokolainen
}

Received: 12 January 2020 / Accepted: 25 April 2021 / Published online: 10 May 2021

(C) The Author(s) 2021

\begin{abstract}
Water scarcity is one of the major problems in the world and millions of people have no access to freshwater. Untreated wastewater is widely used for agriculture in many countries. This is one of the world-leading serious environmental and public health concerns. Instead of using untreated wastewater, treated wastewater has been found more applicable and ecofriendly option. Moreover, environmental toxicity due to solid waste exposures is also one of the leading health concerns. Therefore, intending to combat the problems associated with the use of untreated wastewater, we propose in this review a multidisciplinary approach to handle wastewater as a potential resource for
\end{abstract}

Kavindra Kumar Kesari and Ramendra Soni contributed equally to this work.

K. K. Kesari $(\bowtie) \cdot$ J. Ruokolainen

Department of Applied Physics, Aalto University, Espoo, Finland e-mail: kavindra.kesari@aalto.fi

R. Soni $\cdot$ J. A. Lal $\cdot$ V. Tripathi $(\bowtie)$

Department of Molecular and Cellular Engineering, Sam

Higginbottom University of Agriculture, Technology and

Sciences, Naini, Allahabad, India

e-mail: vijay.tripathi@shiats.edu.in

Q. M. S. Jamal

Department of Health Informatics, College of Public Health and Health Informatics, Qassim University, Al Bukayriyah, Saudi

Arabia

P. Tripathi

Department of Computational Biology and Bioinformatics, Sam

Higginbottom University of Agriculture, Technology and

Sciences, Naini, Allahabad, India use in agriculture. We propose a model showing the efficient methods for wastewater treatment and the utilization of solid wastes in fertilizers. The study also points out the associated health concern for farmers, who are working in wastewater-irrigated fields along with the harmful effects of untreated wastewater. The consumption of crop irrigated by wastewater has leading health implications also discussed in this review paper. This review further reveals that our current understanding of the wastewater treatment and use in agriculture with addressing advancements in treatment methods has great future possibilities.

M. H. Siddiqui $(\bowtie)$

Department of Bioengineering, Faculty of Engineering, Integral University, Lucknow, India

e-mail: mohdharis.siddiqui@gmail.com

P. Kumar

Department of Forestry, NERIST, Nirjuli, Arunachal Pradesh, India 
Keywords Bio-computation · Biomass · Diseases · Environmental pollution · Human health $\cdot$ Sustainable agriculture $\cdot$ Wastewater

\section{Introduction}

Rapidly depleting and elevating the level of freshwater demand, though wastewater reclamation or reuse is one of the most important necessities of the current scenario. Total water consumption worldwide for agriculture accounts 92\% (Clemmens et al., 2008; Hoekstra \& Mekonnen, 2012; Tanji \& Kielen, 2002). Out of which about $70 \%$ of freshwater is used for irrigation (WRI, 2020), which comes from the rivers and underground water sources (Pedrero et al., 2010). The statistics shows serious concern for the countries facing water crisis. Shen et al. (2014) reported that $40 \%$ of the global population is situated in heavy water-stressed basins, which represents the water crisis for irrigation. Therefore, wastewater reuse in agriculture is an ideal resource to replace freshwater use in agriculture (Contreras et al., 2017). Treated wastewater is generally applied for nonpotable purposes, like agriculture, land, irrigation, groundwater recharge, golf course irrigation, vehicle washing, toilet flushes, firefighting, and building construction activities. It can also be used for cooling purposes in thermal power plants (Katsoyiannis et al., 2017; Mohsen, 2004; Smith, 1995; Yang et al., 2017). At global level, treated wastewater irrigation supports agricultural yield and the livelihoods of millions of smallholder farmers (Sato et al., 2013). Global reuse of treated wastewater for agricultural purposes shows wide variability ranging from 1.5 to $6.6 \%$ (Sato et al., 2013; Ungureanu et al., 2018). More than $10 \%$ of the global population consumes agriculture-based products, which are cultivated by wastewater irrigation (WHO, 2006). Treated wastewater reuse has experienced very rapid growth and the volumes have been increased $\sim 10$ to $29 \%$ per year in Europe, the USA, China, and up to 41\% in Australia (Aziz \& Farissi, 2014). China stands out as the leading country in Asia for the reuse of wastewater with an estimated $1.3 \mathrm{M}$ ha area including Vietnam, India, and Pakistan (Zhang \& Shen, 2017). Presently, it has been estimated that, only $37.6 \%$ of the urban wastewater in India is getting treated (Singh et al., 2019). By utilizing $90 \%$ of reclaimed water, Israel is the largest user of treated wastewater for agriculture land irrigation (Angelakis \& Snyder, 2015). The detail information related to the utilization of freshwater and treated wastewater is compiled in Table 1.

Many low-income countries in Africa, Asia, and Latin America use untreated wastewater as a source of irrigation (Jiménez \& Asano, 2008). On the other hand, middle-income countries, such as Tunisia, Jordan, and Saudi Arabia, use treated wastewater for irrigation (AlNakshabandi et al., 1997; Balkhair, 2016a; Balkhair, 2016b; Qadir et al., 2010; Sato et al., 2013).

Domestic water and treated wastewater contains various type of nutrients such as phosphorus, nitrogen, potassium, and sulfur, but the major amount of nitrogen and phosphorous available in wastewater can be easily accumulated by the plants, that's why it is widely used for the irrigation (Drechsel et al., 2010; Duncan, 2009; Poustie et al., 2020; Sengupta et al., 2015). The rich availability of nutrients in reclaimed wastewater reduces the use of fertilizers, increases crop productivity, improves soil fertility, and at the same time, it may also decrease the cost of crop production (Chen et al., 2013a; Jeong et al., 2016). The data of high nutritional values in treated wastewater is shown in Fig. 1.

Wastewater reuse for crop irrigation showed several health concerns (Ungureanu et al., 2020). Irrigation with the industrial wastewater either directly or mixing with domestic water showed higher risk (Chen et al., 2013). Risk factors are higher due to heavy metal and pathogens contamination because heavy metals are nonbiodegradable and have a long biological half-life (Chaoua et al., 2019; WHO, 2006). It contains several toxic elements, i.e., $\mathrm{Cu}, \mathrm{Cr}, \mathrm{Mn}, \mathrm{Fe}, \mathrm{Pb}, \mathrm{Zn}$, and $\mathrm{Ni}$ (Mahfooz et al., 2020). These heavy metals accumulate in topsoil (at a depth of $20 \mathrm{~cm}$ ) and sourcing through plant roots; they enter the human and animal body through leafy vegetables consumption and inhalation of contaminated soils (Mahmood et al., 2014). Therefore, health risk assessment of such wastewater irrigation is important especially in adults (Mehmood et al., 2019; Njuguna et al., 2019; Xiao et al., 2017). For this, an advanced wastewater treatment method should be applied before release of wastewater in the river, agriculture land, and soils. Therefore, this review also proposed an advance wastewater treatment model, which has been tasted partially at laboratory scale by Kesari and Behari (2008), Kesari et al. (2011a, b), and Kumar et al. (2010).

For a decade, reuse of wastewater has also become one of the global health concerns linking to public health and the environment (Dang et al., 2019; Narain et al., 2020). The World Health Organization (WHO) 
Table 1 Freshwater and treated wastewater utilization status in different countries

\begin{tabular}{|c|c|c|c|c|c|}
\hline Country & Water utilizing sectors & & $\begin{array}{l}\text { Status of water reuse (major sectors } \\
\text { reusing water) }\end{array}$ & & Reference \\
\hline \multirow[t]{8}{*}{ Europe } & \multirow[t]{2}{*}{ Agriculture } & \multirow[t]{2}{*}{$44 \%$} & $\begin{array}{l}\text { Landscape irrigation } \\
\text { Groundwater Recharge }\end{array}$ & $\begin{array}{l}20 \% \\
2.2 \%\end{array}$ & \multirow[t]{8}{*}{$\begin{array}{l}\text { EEA CSI, 2018; GWI/PUB Water Reuse } \\
\text { Inventory, } 2009\end{array}$} \\
\hline & & & Recreational & $6.8 \%$ & \\
\hline & \multirow{3}{*}{$\begin{array}{l}\text { Industry and energy } \\
\text { production }\end{array}$} & \multirow[t]{3}{*}{$40 \%$} & Non-potable urban uses & $8.3 \%$ & \\
\hline & & & Indirect potable uses & $2.3 \%$ & \\
\hline & & & Agriculture irrigation & $32 \%$ & \\
\hline & \multirow[t]{3}{*}{ Public water supply } & \multirow[t]{3}{*}{$16 \%$} & Industrial & $19.3 \%$ & \\
\hline & & & Environmental Enhancement & $8 \%$ & \\
\hline & & & Other & $1.5 \%$ & \\
\hline \multirow{6}{*}{$\begin{array}{l}\text { South } \\
\text { Africa }\end{array}$} & Agriculture & $60 \%$ & Landscape and sports field irrigation & $9 \%$ & \multirow[t]{6}{*}{ Adewumia et al., 2010; CoCT, 2007} \\
\hline & Domestic & $27 \%$ & & & \\
\hline & Industrial & $3 \%$ & Industry & $48 \%$ & \\
\hline & Power & $4 \%$ & & & \\
\hline & Mining & $3 \%$ & Agriculture & $43 \%$ & \\
\hline & Other & $3 \%$ & & & \\
\hline \multirow[t]{10}{*}{ USA } & $\begin{array}{l}\text { Freshwater thermoelectric } \\
\text { plants }\end{array}$ & $41 \%$ & Agricultural irrigation & $37 \%$ & \multirow[t]{10}{*}{ Kenny et al., 2009; SWRCB, 2011} \\
\hline & Agricultural irrigation & $37 \%$ & Geothermal energy & $2 \%$ & \\
\hline & Industries & $6 \%$ & Golf course irrigation & $7 \%$ & \\
\hline & Domestic & $14 \%$ & Landscape irrigation & $17 \%$ & \\
\hline & \multirow[t]{6}{*}{ Livestock and aquaculture } & \multirow[t]{6}{*}{$3 \%$} & Groundwater recharge & $12 \%$ & \\
\hline & & & Seawater intrusion barrier & $7 \%$ & \\
\hline & & & Recreational impoundment & $4 \%$ & \\
\hline & & & Wetlands, wildlife habitat & $4 \%$ & \\
\hline & & & Industrial and commercial & $8 \%$ & \\
\hline & & & Other & $2 \%$ & \\
\hline \multirow[t]{4}{*}{ India } & Agriculture & $87 \%$ & Agricultural irrigation & $78 \%$ & \multirow[t]{4}{*}{ Jindal \& Kamat, 2011} \\
\hline & Industrial & $7 \%$ & Industrial use & $12 \%$ & \\
\hline & Domestic & $4 \%$ & Thermal power plant & $4 \%$ & \\
\hline & Energy & $2 \%$ & $\begin{array}{l}\text { Groundwater recharge and artificial } \\
\text { lakes }\end{array}$ & $6 \%$ & \\
\hline \multirow[t]{5}{*}{ Greece } & Irrigation & 83 & Agricultural irrigation & 58.38 & \multirow[t]{5}{*}{ Frontistis et al., 2011; Tsagarakis et al., 2001} \\
\hline & Animal husbandry & 1.3 & $\begin{array}{l}\text { Irrigation of forested land and } \\
\text { firefighting }\end{array}$ & 17.7 & \\
\hline & Industry & 2.2 & Landscape irrigation & 23.92 & \\
\hline & Public use (potable) & 13 & & & \\
\hline & Other & 1.2 & & & \\
\hline
\end{tabular}

drafted guidelines in 1973 to protect the public health by facilitating the conditions for the use of wastewater and excreta in agriculture and aquaculture (WHO, 1973). Later in 2005, the initial guidelines were drafted in the absence of epidemiological studies with minimal risk approach (Carr, 2005). Although, Adegoke et al. (2018) reviewed the epidemiological shreds of evidence and health risks associated with reuse of wastewater for irrigation. Wastewater or graywater reuse has adverse health risks associated with microbial hazards (i.e., infectious pathogens) and chemicals or pharmaceuticals exposures (Adegoke et al., 2016; Adegoke et al., 2017; Busgang et al., 2018; Marcussen et al., 2007; Panthi et al., 2019). Researchers have reported that the exposure to wastewater may cause infectious (helminth infection) diseases, which are linked to anemia and impaired physical and cognitive development (Amoah et al., 2018; Bos et al., 2010; Pham-Duc et al., 2014; WHO, 2006). 
Fig. 1 Nutrient concentrations $(\mathrm{mg} / \mathrm{L})$ of freshwater/wastewater (Yadav et al., 2002)

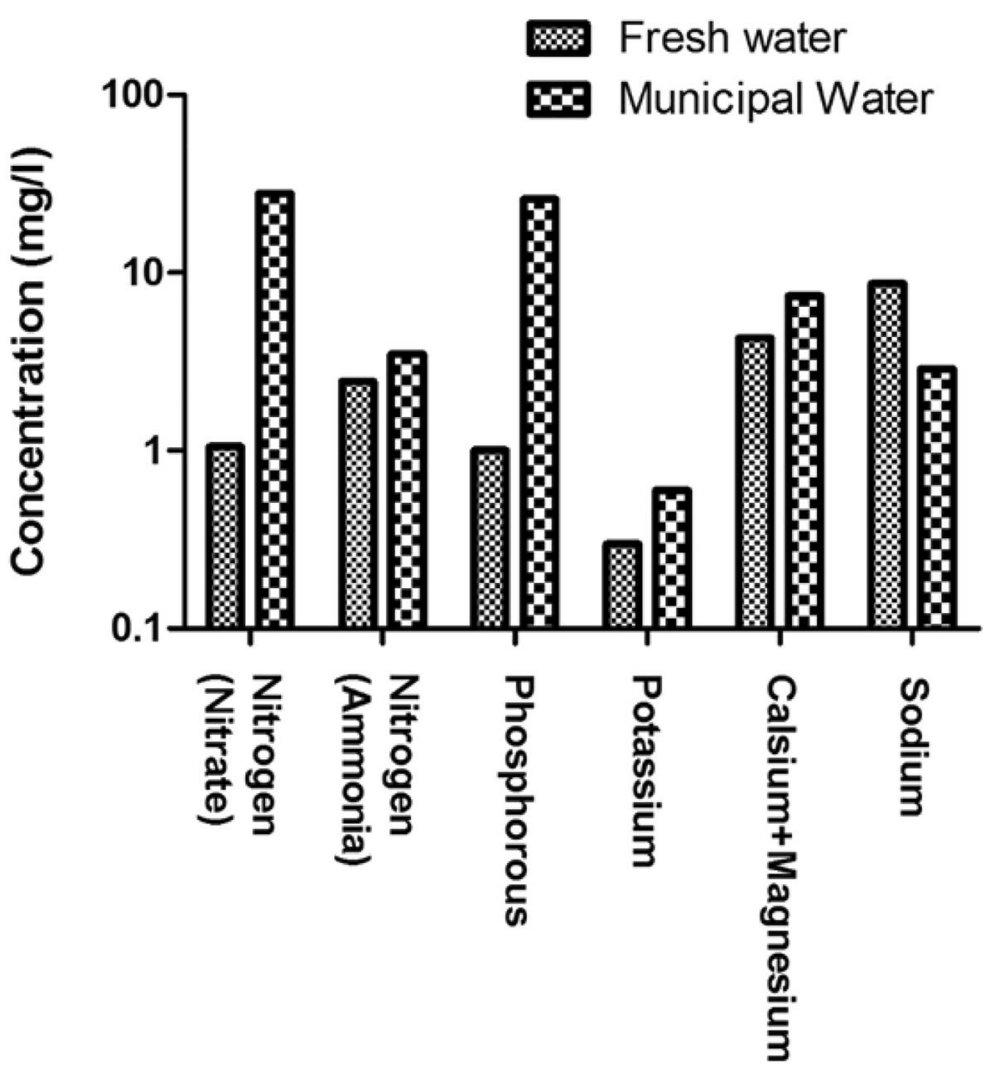

Nutrients
Owing to an increasing population and a growing imbalance in the demand and supply of water, the use of wastewater has been expected to increase in the coming years (World Bank, 2010). The use of treated wastewater in developed nations follows strict rules and regulations. However, the direct use of untreated wastewater without any sound regulatory policies is evident in developing nations, which leads to serious environmental and public health concerns (Dickin et al., 2016). Because of these issues, we present in this review, a brief discussion on the risk associated with the untreated wastewater exposures and advanced methods for its treatment, reuse possibilities of the treated wastewater in agriculture.

\section{Environmental Toxicity of Untreated Wastewater}

Treated wastewater carries larger applicability such as irrigation, groundwater recharge, toilet flushing, and firefighting. Municipal wastewater treatment plants
(WWTPs) are the major collection point for the different toxic elements, pathogenic microorganisms, and heavy metals. It collects wastewater from divergent sources like household sewage, industrial, clinical or hospital wastewater, and urban runoff (Soni et al., 2020). Alghobar et al. (2014) reported that grass and crops irrigated with sewage and treated wastewater are rich in heavy metals in comparison with groundwater (GW) irrigation. Although, heavy metals classified as toxic elements and listed as cadmium, lead, mercury, copper, and iron. An exceeding dose or exposures of these heavy metals could be hazardous for health (Duan et al., 2017) and ecological risks (Tytła, 2019). The major sources of these heavy metals come from drinking water. This might be due to the release of wastewater into river or through soil contamination reaches to ground water. Table 2 presenting the permissible limits of heavy metals presented in drinking water and its impact on human health after an exceeding the amount in drinking water, along with the route of exposure of heavy metals to human body. 
Table 2 Total permissible limits of heavy metals in drinking water and diseases associated with the surplus amount

\begin{tabular}{|c|c|c|c|c|c|}
\hline $\begin{array}{l}\text { Heavy } \\
\text { metals } \\
\text { polluting } \\
\text { the water } \\
\text { quality }\end{array}$ & $\begin{array}{l}\text { Permissible } \\
\text { limits in } \\
\text { drinking water } \\
\text { according to } \\
\text { WHO }(\mathrm{mg} / \mathrm{L})\end{array}$ & $\begin{array}{l}\text { Permissible } \\
\text { limits in } \\
\text { effluent water } \\
\text { according to } \\
\text { WHO }(\mathrm{mg} / \mathrm{L})\end{array}$ & $\begin{array}{l}\text { Diseases associated with the } \\
\text { excess amount }\end{array}$ & Exposure routes & References \\
\hline Arsenic & 0.01 & 5.0 & $\begin{array}{l}\text { Skin, lung, bladder, kidney } \\
\text { cancer, skin manifestations, } \\
\text { gastrointestinal disorders, } \\
\text { neurological effects, hormone } \\
\text { disruption and infertility, } \\
\text { psoriasis }\end{array}$ & Inhalation and ingestion & $\begin{array}{l}\text { Kinuthia et al. (2020) } \\
\text { Kumar et al. (2021); } \\
\text { Punshon et al. (2017); } \\
\text { Jyothi (2020) }\end{array}$ \\
\hline Cadmium & 0.005 & 0.003 & $\begin{array}{l}\text { Psychological disorders, } \\
\text { gastrointestinal disorders, } \\
\text { central nervous system } \\
\text { complications, immune system } \\
\text { deficiencies, DNA impairment, } \\
\text { cancer, Itai-itai disease, } \\
\text { osteoporosis, respiratory dis- } \\
\text { ease }\end{array}$ & $\begin{array}{l}\text { Ingestion of contaminated } \\
\text { food and water and, to a } \\
\text { significant extent, } \\
\text { through inhalation and } \\
\text { cigarette smoking }\end{array}$ & $\begin{array}{l}\text { Kinuthia et al. (2020); } \\
\text { Briffa et al. (2020); } \\
\text { Zhang and Reynolds } \\
\text { (2019); Genchi et al. } \\
\text { (2020); Jyothi (2020) }\end{array}$ \\
\hline Chromium & 0.1 & 0.05 & $\begin{array}{l}\text { Gastrointestinal ulceration, } \\
\text { nausea and vomiting, fever, } \\
\text { diarrhea, toxic nephritis, liver } \\
\text { damage, gingivitis, bronchitis, } \\
\text { pneumonia, lung cancer }\end{array}$ & Inhalation and ingestion & $\begin{array}{l}\text { Kinuthia et al. (2020); } \\
\text { Briffa et al. (2020); } \\
\text { Jyothi (2020) }\end{array}$ \\
\hline Iron & 1.0 & 2.0 & $\begin{array}{l}\text { Genetic disorder, hemorrhagic } \\
\text { necrosis }\end{array}$ & Ingestion & $\begin{array}{l}\text { Yuen and Becker (2020); } \\
\text { Jaishankar et al., 2014; } \\
\text { EPA } 2002 \text {. }\end{array}$ \\
\hline Lead & 0.01 & 0.05 & $\begin{array}{l}\text { Hypertension, miscarriages, } \\
\text { premature and low births, } \\
\text { renal impairment, brain injury, } \\
\text { abdominal pain }\end{array}$ & $\begin{array}{l}\text { Inhalation through the nose } \\
\text { and ingestion through } \\
\text { drinking water and soil }\end{array}$ & $\begin{array}{l}\text { Wani et al. (2015); Goel } \\
\text { et al. (2005); Kinuthia } \\
\text { et al. (2020); Briffa } \\
\text { et al. (2020); } \\
\text { Jyothi (2020), }\end{array}$ \\
\hline Mercury & 0.006 & 0.001 & $\begin{array}{l}\text { Down's syndrome, affects the } \\
\text { reproductive system, speech } \\
\text { defects, memory loss, tremors } \\
\text { and muscle incoordination, } \\
\text { deafness, vision complication }\end{array}$ & $\begin{array}{l}\text { Inhalation, ingestion and } \\
\text { dermal contact }\end{array}$ & $\begin{array}{l}\text { Kinuthia et al. (2020); } \\
\text { Briffa et al. (2020); } \\
\text { Jyothi and } \\
\text { Farook (2020). }\end{array}$ \\
\hline Copper & 2.0 & 0.25 & $\begin{array}{l}\text { Insomnia, anxiety, agitation, } \\
\text { restlessness, fatigue, jaundice, } \\
\text { dizziness }\end{array}$ & Ingestion & $\begin{array}{l}\text { Sharma et al. (2012); } \\
\text { Briffa et al. (2020); } \\
\text { WHO } 2003 \text { Taylor } \\
\text { et al. (2020). } \\
\text { (Agoro et al., 2020) }\end{array}$ \\
\hline Nickel & 0.07 & 0.02 & $\begin{array}{l}\text { Lung embolisms, asthma, } \\
\text { respiratory failure, heart } \\
\text { disorders, dizziness, } \\
\text { increased possibilities of cancer }\end{array}$ & Inhalation and ingestion & $\begin{array}{l}\text { Kinuthia et al. (2020); } \\
\text { Briffa et al. (2020); } \\
\text { Jyothi (2020) }\end{array}$ \\
\hline
\end{tabular}

Direct release in river or reuse of wastewater for irrigation purposes may create short-term implications like heavy metal and microbial contamination and pathogenic interaction in soil and crops. It has also long-term influence like soil salinity, which grows with regular use of untreated wastewater (Smith, 1995). Improper use of wastewater for irrigation makes it unsafe and environment threatening. Irrigation with several different types of wastewater, i.e., industrial effluents, municipal and agricultural wastewaters, and sewage liquid sludge transfers the heavy metals to the soil, which leads to accumulation in crops due to improper practices. This has been identified as a significant route of heavy metals into aquatic resources (Agoro et al., 2020). Hussain et al. 
(2019) investigated the concentration of heavy metals (except for $\mathrm{Cd}$ ) was higher in the soil irrigated with treated wastewater (large-scale sewage treatment plant) than the normal ground water, also reported by Khaskhoussy et al. (2015).

In other words, irrigation with wastewater mitigates the quality of crops and enhances health risks. Excess amount of copper causes anemia, liver and kidney damage, vomiting, headache, and nausea in children (Bent \& Bohm, 1995; Madsen et al., 1990; Salem et al., 2000). A higher concentration of arsenic may lead to bone and kidney cancer (Jarup, 2003) and results in osteopenia or osteoporosis (Puzas et al., 2004). Cadmium gives rise to musculoskeletal diseases (Fukushima et al., 1970), whereas mercury directly affects the nervous system (Azevedo et al., 2014).

\section{Spread of Antibiotic Resistance}

Currently, antibiotics are highly used for human disease treatment; however, uses in poultries, animal husbandries, biochemical industries, and agriculture are common practices these days. Extensive use and/or misuse of antibiotics have given rise to multi-resistant bacteria, which carry multiple resistance genes (Icgen \& Yilmaz, 2014; Lv et al., 2015; Tripathi \& Tripathi, 2017; Xu et al., 2017). These multidrug-resistant bacteria discharged through the sewage network and get collected into the wastewater treatment plants. Therefore, it can be inferred that the WWTPs serve as the hotspot of antibiotic-resistant bacteria (ARB) and antibiotic resistance genes (ARGs). Though, these antibiotic-resistant bacteria can be disseminated to the different bacterial species through the mobile genetic elements and horizontal gene transfer (Gupta et al., 2018). Previous studies indicated that certain pathogens might survive in wastewater, even during and after the treatment processes, including methicillin-resistant Staphylococcus aureus (MRSA) and vancomycinresistant enterococci (VRE) (Börjesson et al., 2009; Caplin et al., 2008). The use of treated wastewater in irrigation provides favorable conditions for the growth and persistence of total coliforms and fecal coliforms (Akponikpe et al., 2011; Sacks \& Bernstein, 2011). Furthermore, few studies have also reported the presence of various bacterial pathogens, such as Clostridium, Salmonella, Streptococci, Viruses, Protozoa, and Helminths in crops irrigated with treated wastewater
(Carey et al., 2004; Mañas et al., 2009; Samie et al., 2009). Goldstein (2013) investigated the survival of ARB in secondary treated wastewater and proved that it causes serious health risks to the individuals, who are exposed to reclaimed water. The U.S. Centers for Disease Control and Prevention (CDC) and the World Health Organization (WHO) have already declared the ARBs as the imminent hazard to human health. According to the list published by WHO, regarding the development of new antimicrobial agents, the ESKAPE (Enterococcus faecium, S. aureus, Klebsiella pneumoniae, Acinetobacter baumannii, Pseudomonas aeruginosa, and Enterobacter species) pathogens were designated to be "priority status" as their occurrence in the food chain is considered as the potential and major threat for the human health (Tacconelli et al., 2018).

These ESKAPE pathogens have acquired the multi drug resistance mechanisms against oxazolidinones, lipopeptides, macrolides, fluoroquinolones, tetracyclines, $\beta$-lactams, $\beta$-lactam- $\beta$-lactamase inhibitor combinations, and even those antibiotics that are considered as the last line of defense, including carbapenems and glycopeptides (Giddins et al., 2017; Herc et al., 2017; Iguchi et al., 2016; Naylor et al., 2018; Zaman et al., 2017), by the means of genetic mutation and mobile genetic elements. These cluster of ESKAPE pathogens are mainly responsible for lethal nosocomial infections (Founou et al., 2017; Santajit \& Indrawattana, 2016).

Due to the wide application of antibiotics in animal husbandry and inefficient capability of wastewater treatment plants, the multidrug-resistant bacteria such as tetracyclines, sulfonamides, $\beta$-lactam, aminoglycoside, colistin, and vancomycin in major are disseminated in the receiving water bodies, which ultimately results in the accumulation of ARGs in the irrigated crops (He et al., 2020).

\section{Toxic Contaminations in Wastewater Impacting Human Health}

The release of untreated wastewater into the river may pose serious health implications (König et al., 2017; Odigie, 2014; Westcot, 1997). It has been already discussed about the household and municipal sewage which contains a major amount of organic materials and pathogenic microorganisms and these infectious microorganisms are capable of spreading various diseases like typhoid, dysentery, diarrhea, vomiting, and 
malabsorption (Jia \& Zhang, 2020; Numberger et al., 2019; Soni et al., 2020). Additionally, pharmaceutical industries also play a key role in the regulation and discharge of biologically toxic agents. The untreated wastewater also contains a group of contaminants, which are toxic to humans. These toxic contaminations have been classified into two major groups: (i) chemical contamination and (ii) microbial contamination.

\subsection{Chemical Contamination}

Mostly, various types of chemical compounds released from industries, tanneries, workshops, irrigated lands, and household wastewaters are responsible for several diseases. These contaminants can be organic materials, hydrocarbons, volatile compounds, pesticides, and heavy metals. Exposure to such contaminants may cause infectious diseases like chronic dermatoses and skin cancer, lung infection, and eye irritation. Most of them are non-biodegradable and intractable. Therefore, they can persist in the water bodies for a very long period and could be easily accumulated in our food chain system. Several pharmaceutical personal care products (PPCPs) and surfactants are available that may contain toxic compounds like nonylphenol, estrone, estradiol, and ethinylestradiol. These compounds are endocrine-disrupting chemicals (Bolong et al., 2009), and the existence of these compounds in the human body even in the trace amounts can be highly hazardous. Also, the occurrence of perfluorinated compounds (PFCs) in wastewater, which is toxic in nature, has been significantly reported worldwide (Templeton et al., 2009). Furthermore, PFCs cause severe health menaces like pre-eclampsia, birth defects, reduced human fertility (Webster, 2010), immunotoxicity (Dewitt et al., 2012), neurotoxicity (Lee \& Viberg, 2013), and carcinogenesis (Bonefeld-Jorgensen et al., 2011).

\subsection{Microbial Contamination}

Researchers have reported serious health risks associated with the microbial contaminants in untreated wastewater. The diverse group of microorganisms causes severe health implications like campylobacteriosis, diarrhea, encephalitis, typhoid, giardiasis, hepatitis A, poliomyelitis, salmonellosis, and gastroenteritis (ISDH, 2009; Okoh et al., 2010). Few bacterial species like P. aeruginosa, Salmonella typhimurium, Vibrio cholerae, G. intestinales, Legionella spp., E. coli,
Shigella sonnei have been reported for the spreading of waterborne diseases, and acute illness in human being (Craun et al., 2006; Craun et al., 2010). These aforementioned microorganisms may release in the environment from municipal sewage water network, animal husbandries, or hospitals and enter the food chain via public water supply systems.

\section{Wastewater Impact on Agriculture}

The agriculture sector is well known for the largest user of water, accounting for nearly $70 \%$ of global water usage (Winpenny et al., 2010). The fact that an estimated 20 million hectares worldwide are irrigated with wastewater suggests a major source for irrigation (Ecosse, 2001). However, maximum wastewater that is used for irrigation is untreated (Jiménez \& Asano, 2008; Scott et al., 2004). Mostly in developing countries, partially treated or untreated wastewater is used for irrigation purpose (Scott et al., 2009). Untreated wastewater often contains a large range of chemical contaminants from waste sites, chemical wastes from industrial discharges, heavy metals, fertilizers, textile, leather, paper, sewage waste, food processing waste, and pesticides. World Health Organization (WHO) has warned significant health implications due to the direct use of wastewater for irrigation purposes (WHO, 2006). These contaminants pose health risks to communities (farmers, agricultural workers, their families, and the consumers of wastewater-irrigated crops) living in the proximity of wastewater sources and areas irrigated with untreated wastewater (Qadir et al., 2010). Wastewater also contains a wide variety of organic compounds. Some of them are toxic or cancer-causing and have harmful effects on an embryo (Jarup, 2003; Shakir et al., 2016). The pathway of untreated wastewater used in irrigation and associated health effects are shown in Fig. 2.

Alternatively, in developing countries, due to the limited availability of treatment facilities, untreated wastewater is discharged into the existing waterbodies (Qadir et al., 2010). The direct use of wastewater in agriculture or irrigation obstructs the growth of natural plants and grasses, which in turn causes the loss of biodiversity. Shuval et al. (1985) reported one of the earliest evidences connecting to agricultural wastewater reuse with the occurrence of diseases. Application of untreated wastewater in irrigation increases soil salinity, land sealing followed by sodium accumulation, which 


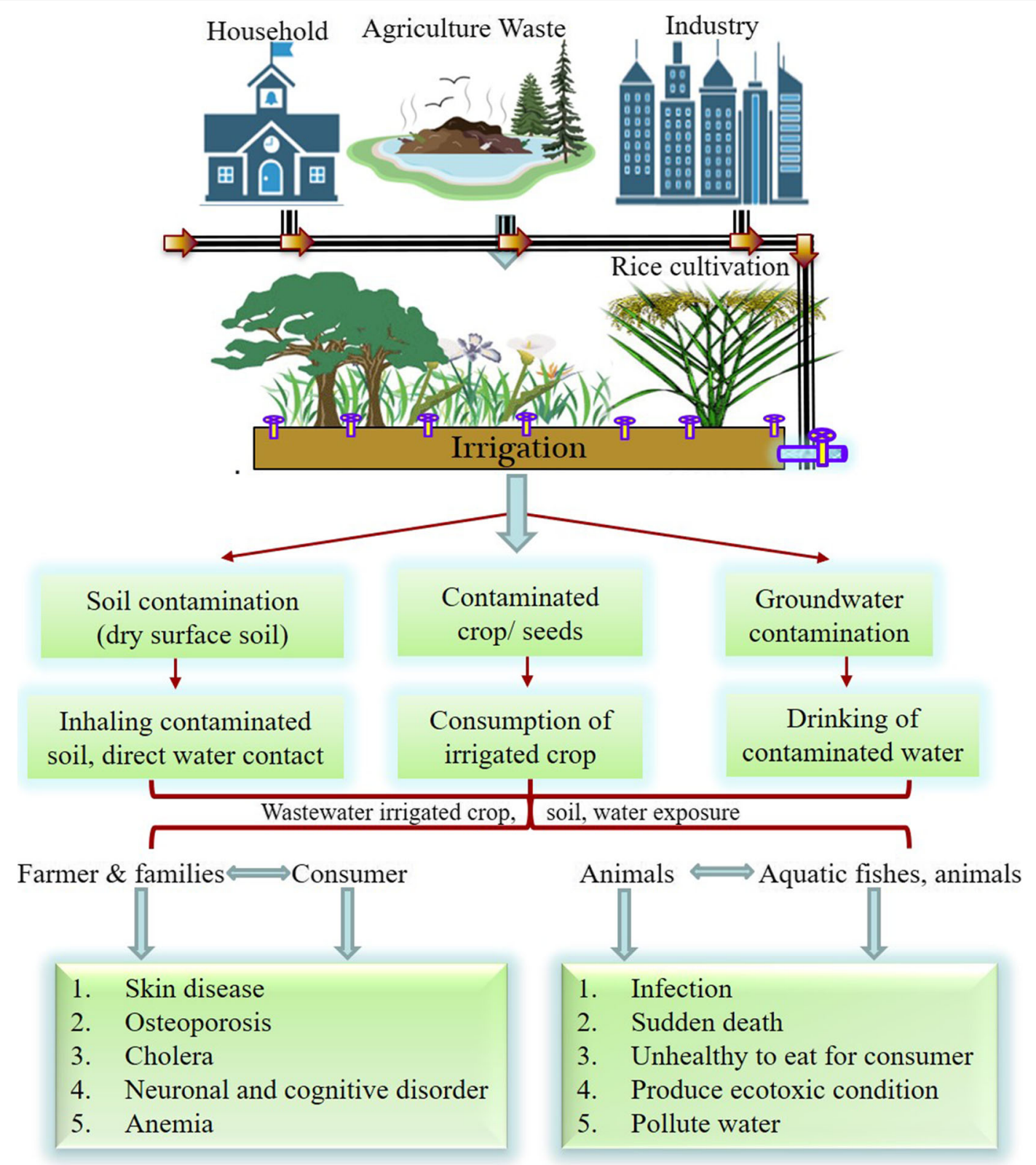

Fig. 2 Exposure pathway representing serious health concerns from wastewater-irrigated crops

results in soil erosion. Increased soil salinity and sodium accumulation deteriorates the soil and decreases the soil permeability, which inhibits the nutrients intake of crops from the soil. These causes have been considered the long-term impact of wastewater reuse in agriculture (Halliwell et al., 2001). Moreover, wastewater contaminated soils are a major source of intestinal parasites (helminths - nematodes and tapeworms) that are transmitted through the fecal-oral route (Toze, 1997).
Already known, the helminth infections are linked to blood deficiency and behavioral or cognitive development (Bos et al., 2010). One of the major sources of helminth infections around the world is the use of raw or partially treated sewage effluent and sludge for the irrigation of food crops (WHO, 1989). Wastewaterirrigated crops contain heavy metal contamination, which originates from mining, foundries, and metalbased industries (Fazeli et al., 1998). Exposure to heavy 
metals including arsenic, cadmium, lead, and mercury in wastewater-irrigated crops is a cause for various health problems. For example, the consumption of high amounts of cadmium causes osteoporosis in humans (Dickin et al., 2016). The uptake of heavy metals by the rice crop irrigated with untreated effluent from a paper mill has been reported to cause serious health concerns (Fazeli et al., 1998). Irrigating rice paddies with highly contaminated water containing heavy metals leads to the outbreak of Itai-itai disease in Japan (Jarup, 2003).

Owing to these widespread health risks, the WHO published the third edition of its guidelines for the safe use of wastewater in irrigating crops (WHO, 2006) and made recommendations for threshold contaminant levels in wastewater. The quality of wastewater for agricultural reuse have been classified based on the availability of nutrients, trace elements, microorganisms, and chemicals contamination levels. The level of contamination differs widely depending on the type of source, household sewage, pharmaceutical, chemical, paper, or textile industries effluents. The standard measures of water quality for irrigation are internationally reported (CCREM, 1987; FAO, 1985; FEPA, 1991; US EPA, 2004, 2012; WHO, 2006), where the recommended levels of trace elements, metals, COD, BOD, nitrogen, and phosphorus are set at certain limits. Researchers reviewed the status of wastewater reuse for agriculture, based on its standards and guidelines for water quality (Angelakis et al., 1999; Brissaud, 2008; Kalavrouziotis et al., 2015). Based on these recommendations and guidelines, it is evident that greater awareness is required for the treatment of wastewater safely.

\section{Wastewater Treatment Techniques}

\subsection{Primary Treatment}

This initial step is designed to remove gross, suspended and floating solids from raw wastewater. It includes screening to trap solid objects and sedimentation by gravity to remove suspended solids. This physical solid/liquid separation is a mechanical process, although chemicals can be used sometimes to accelerate the sedimentation process. This phase of the treatment reduces the BOD of the incoming wastewater by $20-30 \%$ and the total suspended solids by nearly $50-60 \%$.
6.2 Secondary (Biological) Treatment

This stage helps eliminate the dissolved organic matter that escapes primary treatment. Microbes consume the organic matter as food, and converting it to carbondioxide, water, and energy for their own growth. Additional settling to remove more of the suspended solids then follows the biological process. Nearly $85 \%$ of the suspended solids and biological oxygen demand (BOD) can be removed with secondary treatment. This process also removes carbonaceous pollutants that settle down in the secondary settling tank, thus separating the biological sludge from the clear water. This sludge can be fed as a co-substrate with other wastes in a biogas plant to obtain biogas, a mixture of $\mathrm{CH}_{4}$ and $\mathrm{CO}_{2}$. It generates heat and electricity for further energy distribution. The leftover, clear water is then processed for nitrification or denitrification for the removal of carbon and nitrogen. Furthermore, the water is passed through a sedimentation basin for treatment with chlorine. At this stage, the water may still contain several types of microbial, chemical, and metal contaminations. Therefore, to make the water reusable, e.g., for irrigation, it further needs to pass through filtration and then into a disinfection tank. Here, sodium hypochlorite is used to disinfect the wastewater. After this process, the treated water is considered safe to use for irrigation purposes. Solid wastes generated during primary and secondary treatment processes are processed further in the gravitythickening tank under a continuous supply of air. The solid waste is then passed into a centrifuge dewatering tank and finally to a lime stabilization tank. Treated solid waste is obtained at this stage and it can be processed further for several uses such as landfilling, fertilizers and as a building.

Other than the activated sludge process of wastewater treatment, there are several other methods developed and being used in full-scale reactors such as ponds (aerobic, anaerobic, facultative, and maturation), trickling filters, anaerobic treatments like up-flow anaerobic sludge blanket (UASB) reactors, artificial wetlands, microbial fuel cells, and methanogenic reactors.

UASB reactors are being applied for wastewater treatment from a very long period. Behling et al. (1996) examined the performance of the UASB reactor without any external heat supply. In their study, the COD loading rate was maintained at $1.21 \mathrm{~kg} \mathrm{COD} / \mathrm{m}^{3} /$ day, after 200 days of trial. They achieved an average of $85 \%$ of COD removal. Von-Sperling and Chernicharo 
(2005) presented a combined model consisted of an Upflow Anaerobic Sludge Blanket-Activated Sludge reactor (UASB-AS system), using the low strength domestic wastewater with a $\mathrm{BOD}_{5}$ amounting to $340 \mathrm{mg} / \mathrm{l}$. Outcomes of their experiment have shown a $60 \%$ reduction in sludge construction and a $40 \%$ reduction in aeration energy consumption. In another experiment, Rizvi et al. (2015) seeded UASB reactor with cow manure dung to treat domestic wastewater; they observed $81 \%, 75 \%$, and $76 \%$ reduction in COD, TSS, and total sulfate removal, respectively, in their results.

\subsection{Tertiary or Advanced Treatment Processes}

The tertiary treatment process is employed when specific constituents, substances, or contaminants cannot be completely removed after the secondary treatment process. The tertiary treatment processes, therefore, ensure that nearly $99 \%$ of all impurities are removed from wastewater. To make the treated water safe for drinking purposes, water is treated individually or in combination with advanced methods like the US (ultrasonication), UV (ultraviolet light treatment), and $\mathrm{O}_{3}$ (exposure to ozone). This process helps to remove bacteria and heavy metal contaminations remaining in the treated water. For the purpose, the secondarily treated water is first made to undergo ultrasonication and it is subsequently exposed to UV light and passed through an ozone chamber for the complete removal of contaminations. The possible mechanisms by which cells are rendered inviable during the US include free-radical attack and physical disruption of cell membranes (Phull et al., 1997; Scherba et al., 1991). The combined treatment of US + $\mathrm{UV}+\mathrm{O}_{3}$ produces free radicals, which are attached to cell membranes of the biological contaminants. Once the cell membrane is sheared, chemical oxidants can enter the cell and attack internal structures. Thus, the US alone or in combination facilitates the deagglomeration of microorganisms and increases the efficiency of other chemical disinfectants (Hua \& Thompson, 2000; Kesari et al., 2011a, b; Petrier et al., 1992; Phull et al., 1997; Scherba et al., 1991). A combined treatment method was also considered by Pesoutova et al. (2011) and reported a very effective method for textile wastewater treatment. The effectiveness of ultrasound application as a pre-treatment step in combination with ultraviolet rays (Blume \& Neis, 2004; Naddeo et al., 2009), or also compared it with various other combinations of both ultrasound and UV radiation with $\mathrm{TiO}_{2}$ photocatalysis (Paleologou et al., 2007), and ozone (Jyoti \& Pandit, 2004) to optimize wastewater disinfection process.

An important aspect of our wastewater treatment model (Fig. 3) is that at each step of the treatment process, we recommend the measurement of the quality of treated water. After ensuring that the proper purification standards are met, the treated water can be made available for irrigation, drinking or other domestic uses.

\subsection{Nanotechnology as Tertiary Treatment of Wastewater Converting Drinking Water Alike}

Considering the emerging trends of nanotechnology, nanofillers can be used as a viable method for the tertiary treatment of wastewater. Due to the very small pore size, $1-5-\mathrm{nm}$ nanofillers may eliminate the organic-inorganic pollutants, heavy metals, as well as pathogenic microorganisms and pharmaceutically active compounds (PhACs) (Mohammad et al., 2015; Vergili, 2013). Over the recent years, nanofillers have been largely accepted in the textile industry for the treatment of pulp bleaching pharmaceutical industry, dairy industry, microbial elimination, and removal of heavy metals from wastewater (Abdel-Fatah, 2018). Srivastava et al. (2004) synthesized very efficient and reusable water filters from carbon nanotubes, which exhibited effective elimination of bacterial pathogens (E. coli and S. aureus), and Poliovirus sabin-1 from wastewater.

Nanofiltration requires lower operating pressure and lesser energy consumption in comparison of $\mathrm{RO}$ and higher rejection of organic compounds compared to UF. Therefore, it can be applied as the tertiary treatment of wastewater (Abdel-Fatah, 2018). Apart from nanofilters, there are various kinds of nanoparticles like metal nanoparticles, metal oxide nanoparticles, carbon nanotubes, graphene nanosheets, and polymer-based nanosorbents, which may play a different role in wastewater treatment based on their properties. Kocabas et al. (2012) analyzed the potential of different metal oxide nanoparticles and observed that nanopowders of $\mathrm{TiO}_{2}$, $\mathrm{FeO}_{3}, \mathrm{ZnO}_{2}$, and $\mathrm{NiO}$ can exhibit the exceeding amount of removal of arsenate from wastewater. Cadmium contamination in wastewater, which poses a serious health risk, can be overcome by using $\mathrm{ZnO}$ nanoparticles (Kumar \& Chawla, 2014). Latterly, Vélez et al. (2016) investigated that the $70 \%$ removal of mercury from wastewater through iron oxide nanoparticles 


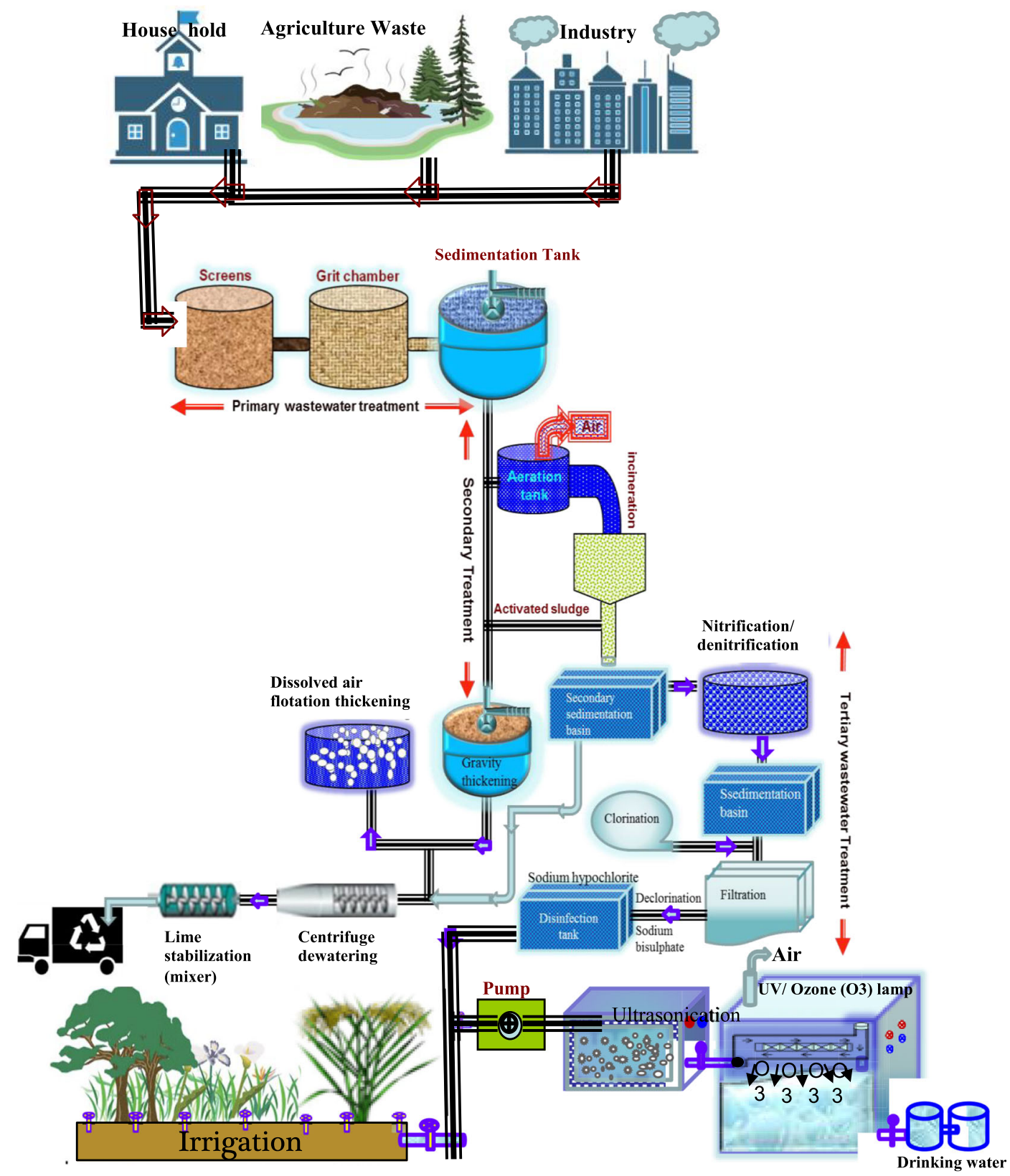

Fig. 3 A wastewater treatment schematic highlighting the various methods that result in a progressively improved quality of the wastewater from the source to the intended use of the treated wastewater for irrigation purposes

successfully performed. Sheet et al. (2014) used graphite oxide nanoparticles for the removal of nickel from wastewater. An exceeding amount of copper causes liver cirrhosis, anemia, liver, and kidney damage, which can be removed by carbon nanotubes, pyromellitic acid dianhydride (PMDA) and phenyl aminomethyl trimethoxysilane (PAMTMS) (Liu et al., 2010).
Nanomaterials are efficiently being used for microbial purification from wastewater. Carbon nanotubes (CNTs) are broadly applied for the treatment of wastewater contaminated with E. coli, Salmonella, and a wide range of microorganisms (Akasaka \& Watari, 2009). In addition, silver nanoparticles reveal very effective results against the microorganisms present in wastewater. 
Hence, it is extensively being used for microbial elimination from wastewater (Inoue et al., 2002). Moreover, CNTs exhibit high binding affinity to bacterial cells and possess magnetic properties (Pan \& Xing, 2008). Melanta (2008) confirmed and recommended the applicability of CNTs for the removal of E. coli contamination from wastewater. Mostafaii et al. (2017) suggested that the $\mathrm{ZnO}$ nanoparticles could be the potential antibacterial agent for the removal of total coliform bacteria from municipal wastewater. Apart from the previously mentioned, applicability of the nanotechnology, the related drawbacks and challenges cannot be neglected. Most of the nanoengineered techniques are currently either in research scale or pilot scale performing well (Gehrke et al., 2015). Nevertheless, as discussed above, nanotechnology and nanomaterials exhibit exceptional properties for the removal of contaminants and purification of water. Therefore, it can be adapted as the prominent solution for the wastewater treatment (Zekić et al., 2018) and further use for drinking purposes.

\subsection{Wastewater Treatment by Using Plant Species}

Some of the naturally growing plants can be a potential source for wastewater treatment as they remove pollutants and contaminants by utilizing them as a nutrient source (Zimmels et al., 2004). Application of plant species in wastewater treatment may be costeffective, energy-saving, and provides ease of operation. At the same time, it can be used as in situ, where the wastewater is being produced (Vogelmann et al., 2016). Nizam et al. (2020) analyzed the phytoremediation efficiency of five plant species (Centella asiatica, Ipomoea aquatica, Salvinia molesta, Eichhornia crassipes, and Pistia stratiotes) and achieved the drastic decrease in the amount of three pollutants viz. total suspended solids (TSS), ammoniacal nitrogen $\left(\mathrm{NH}_{3}-\mathrm{N}\right)$, and phosphate levels. All the five species found to be efficient removal of the level of $63.9-98 \%$ of $\mathrm{NH}_{3}-\mathrm{N}$, TSS, and phosphate. Coleman et al. (2001) examined the physiological effects of domestic wastewater treatment by three common Appalachian plant species: common rush or soft rush (Juncus effuses L.), gray club-rush (Scirpus Validus L.), and broadleaf cattail or bulrush (Typha latifolia L.). They observed in their experiments about $70 \%$ of reduction in total suspended solids (TSS) and biochemical oxygen demand (BOD), $50 \%$ to $60 \%$ of reduction in nitrogen, ammonia, and phosphate levels, and a significant reduction in feacal coliform populations. Whereas, Zamora et al. (2019) found the removal efficiency of chemical oxygen demand (COD), total solids suspended (TSS), nitrogen as ammonium $\left(\mathrm{N}_{-} \mathrm{NH}_{4}\right)$ and nitrate $\left(\mathrm{N}-\mathrm{NO}_{3}\right)$, and phosphate $\left(\mathrm{P}-\mathrm{PO}_{4}\right)$ up to

Table 3 Various plant species applied for the wastewater remediation and their effects

\begin{tabular}{|c|c|c|c|c|}
\hline S.N. & Plant species & Common name & Effects & References \\
\hline 1. & $\begin{array}{l}\text { Juncus } \\
\qquad \text { effusus L. }\end{array}$ & Common rush or soft rush & $\begin{array}{l}\text { Reduction of BOD, COD, TSS, } \\
\text { nitrogen, phosphate, and fecal coliforms }\end{array}$ & Coleman et al. (2001) \\
\hline 2. & $\begin{array}{l}\text { Scirpus } \\
\quad \text { validus } \mathrm{L} .\end{array}$ & Grey club-rush & & \\
\hline 3. & $\begin{array}{l}\text { Typha } \\
\text { latifolia } \\
\text { L. }\end{array}$ & Broadleaf cattail or bulrush & & \\
\hline 4. & $\begin{array}{l}\text { Azolla } \\
\quad \text { californi- } \\
\quad \text { ana }\end{array}$ & Fairy moss & Reduction of turbidity BOD, COD, and TSS & $\begin{array}{l}\text { Jacquez and Walner } \\
\quad(1985)\end{array}$ \\
\hline 5. & $\begin{array}{l}\text { Oenanthe } \\
\text { javanica }\end{array}$ & $\begin{array}{l}\text { Chinese celery, Indian } \\
\text { pennywort, Japanese } \\
\text { parsley, }\end{array}$ & $\begin{array}{l}\text { Influences dissolved oxygen, } \mathrm{pH} \text {, and temperature } \\
\text { wastewater purification and nutrient uptake }\end{array}$ & $\begin{array}{l}\text { Zhou and Wang (2010); } \\
\text { Zhu et al. (2011) }\end{array}$ \\
\hline 6. & $\begin{array}{l}\text { Hydrocotyle } \\
\text { vulgaris }\end{array}$ & marsh pennywort & Removal of total nitrogen and $\mathrm{NH}_{4}{ }^{-}$nitrogen & Duan et al. (2016). \\
\hline 7. & $\begin{array}{l}\text { Ipomoea } \\
\text { aquatica }\end{array}$ & $\begin{array}{l}\text { Swamp morning or water } \\
\text { spinach }\end{array}$ & & \\
\hline 8. & $\begin{array}{l}\text { Eichornia } \\
\text { crassipes }\end{array}$ & Water hyacinth & $\begin{array}{l}\text { Reduction of ammonia, nitrate BOD, COD, TSS, } \\
\text { turbidity, and heavy metals }\end{array}$ & $\begin{array}{l}\text { Brumer (2000); Jacquez } \\
\text { and Walner (1985) }\end{array}$ \\
\hline
\end{tabular}


20-60\% higher using the three ornamental species of plants viz. Canna indica, Cyperus papyrus, and Hedychium coronarium. The list of various plant species applied for the wastewater treatment is shown in Table 3.

\subsection{Wastewater Treatment by Using Microorganisms}

There is a diverse group of bacteria like Pseudomonas fluorescens, Pseudomonas putida, and different Bacillus strains, which are capable to use in biological wastewater systems. These bacteria work in the cluster forms as a floc, biofilm, or granule during the wastewater treatment. Furthermore, after the recognition of bacterial exopolysaccharides (EPS) as an efficient adsorption material, it may be applied in a revolutionary manner for the heavy metal elimination (Gupta \& Diwan, 2017). There are few examples of EPS, which are commercially available, i.e., alginate ( $P$. aeruginosa, Azotobacter vinelandii), gellan (Sphingomonas paucimobilis), hyaluronan (. aeruginosa, Pasteurella multocida, Streptococci attenuated strains), xanthan (Xanthomonas campestris), and galactopol (Pseudomonas oleovorans) (Freitas et al., 2009; Freitas, Alves, \& Reis, 2011a; Freitas, Alves, Torres, et al., 2011b). Similarly, Hesnawi et al. (2014) experimented biodegradation of municipal wastewater using local and commercial bacteria (Sludge Hammer), where they achieved a significant decrease in synthetic wastewater, i.e., $70 \%, 54 \%, 52 \%, 42 \%$ for the Sludge Hammer, B. subtilis, B. laterosponus, and P. aeruginosa, respectively. Therefore, based on the above studies, it can be concluded that bioaugmentation of wastewater treatment reactor with selective and mixed strains can ameliorate the treatment. During recent years, microalgae have attracted the attention of researchers as an alternative system, due to their applicability in wastewater treatment. Algae are the unicellular or multicellular photosynthetic microorganism that grows on water surfaces, salt water, or moist soil. They utilize the exceeding amount of nutrients like nitrogen, phosphorus, and carbon for their growth and metabolism process through their anaerobic system. This property of algae also inhibits eutrophication; that is to avoid over-deposit of nutrients in water bodies. During the nutrient digestion process, algae produce oxygen that is constructive for the heterotrophic aerobic bacteria, which may further be utilized to degrade the organic and inorganic pollutants. Kim et al. (2014) observed a total decrease in the levels of COD $(86 \%)$, total nitrogen $(93 \%)$, and total phosphorus $(83 \%)$ after using algae in the municipal wastewater consortium. Nmaya et al. (2017) reported the heavy metal removal efficiency of microalga Scenedesmus sp. from contaminated river water in the Melaka River, Malaysia. They observed the effective removal of $\mathrm{Zn}(97-99 \%)$ on the $3^{\text {rd }}$ and $7^{\text {th }}$ day of the experiment. The categorized list of microorganisms used for wastewater treatment is presented in Table 4.

\section{The Computational Approach in Wastewater Treatment}

\subsection{Bioinformatics and Genome Sequencing}

A computational approach is accessible in wastewater treatment. Several tools and techniques are in use such as, sequencing platforms (Hall, 2007; Marsh, 2007), metagenome sequencing strategies (Schloss \& Handelsman, 2005; Schmeisser et al., 2007; Tringe et al., 2005), bioinformatics tools and techniques (Chen \& Pachter, 2005; Foerstner et al., 2006; Raes et al., 2007), and the genome analysis of complex microbial communities (Fig. 4). Most of the biological database contains microorganisms and taxonomical information. Thus, these can provide extensive details and supports for further utilization in wastewater treatmentrelated research and development (Siezen \& Galardini, 2008). Balcom et al. (2016) explored that the microbial population residing in the plant roots immersed in the wastewater of an ecological WWTP and showed the evidence of the capacity for micro-pollutant biodegradation using whole metagenome sequencing (WMS). Similarly, Kumar et al. (2016) revealed that bioremediation of highly polluted wastewater from textile dyes by two novel strains were found to highly decolorize Joyfix Red. They were identified as Lysinibacillus sphaericus (KF032717) and Aeromonas hydrophila (KF032718) through 16S rDNA analysis. More recently, Leddy et al. (2018) reported that research scientists are making strides to advance the safety and application of potable water reuse with metagenomics for water quality analysis. The application of the bio-computational approach has also been implemented in the advancements of wastewater treatment and disease detection. 
Table 4 Microorganisms applied for wastewater treatment

\begin{tabular}{|c|c|c|c|}
\hline S.N & Species & Effects & References \\
\hline \multicolumn{4}{|c|}{ Algae } \\
\hline 1. & Scenedesmus sp. & Removal of heavy metal $(\mathrm{Zn})$ from wastewater & Nmaya et al. (2017) \\
\hline 2. & Scenedesmus abundans & Removal of $\mathrm{Cd}$ and $\mathrm{Cu}$, detoxification of cyanide from wastewater. & Oilgae (2014) \\
\hline 3. & Botryococcus braunii & $\begin{array}{l}\text { Removal of nitrogen, phosphorus, and other inorganic compounds } \\
\text { from industrial wastewater }\end{array}$ & Oilgae (2014) \\
\hline 4. & Dunaliella salina & $\begin{array}{l}\text { Eliminates } \mathrm{Cu}, \mathrm{Cd}, \mathrm{Co} \text {, and } \mathrm{Zn} \text { from polluted water, } \\
\text { applied in the treatment of hypersaline wastewater }\end{array}$ & Oilgae (2014) \\
\hline 5. & Sargassum muticum & Removes Methylene Blue dye from wastewater. & Oilgae (2014) \\
\hline 6. & Chlorella sp. & $\begin{array}{l}\text { Removal of lead (II), N, P, } \\
\text { and detoxification of cyanide from wastewater } \\
\text { Fungi }\end{array}$ & Oilgae (2014) \\
\hline 1. & Bjerkandera adusta MUT 2295, & Effective in wastewater decolourisation and detoxification & $\begin{array}{c}\text { Anastasi et al. (2010); } \\
\text { Spina et al. (2012) }\end{array}$ \\
\hline 2. & $\begin{array}{l}\text { Phanerochaete chrysosporium } \\
\text { (white-rot fungi) }\end{array}$ & Degrade several aromatic compounds & Spina et al. (2012) \\
\hline 3. & Trametes versicolor & $\begin{array}{l}\text { Wastewater decolourisation, humic acid removal from industrial } \\
\text { wastewater }\end{array}$ & Zahmatkesh et al. (2018) \\
\hline 4. & Rhizopus arrhizus & Biosorption of heavy metals & Sağ (2001) \\
\hline 5. & Fusarium flocciferum & Absorption of $\mathrm{Ni}(\mathrm{II})$ and $\mathrm{Cd}(\mathrm{II})$ from wastewater & Delgado et al. (1998) \\
\hline 6. & Penicillium chrysogenum & Absorption of $\mathrm{Cd}(\mathrm{II})$ from wastewater & Volesky (1994) \\
\hline \multicolumn{4}{|c|}{ Bacteria } \\
\hline 1. & Sphingomonas sp. strain BN6 & $\begin{array}{l}\text { Degrades naphthalene-2-sulphonate (a building block of azo dyes) } \\
\text { present in contaminated water }\end{array}$ & Russ et al. (2000) \\
\hline 2. & Paenibacillus azoreducens & Color removal from wastewater with $98 \%$ efficiency & Meehan et al. (2001) \\
\hline 3. & Pseudomonas luteola & Decoloration of wastewater & Chang et al. (2001) \\
\hline $\begin{array}{l}4 . \\
5 .\end{array}$ & $\begin{array}{l}\text { Bacillus subitlis } \\
\text { Bacillus laterosponus }\end{array}$ & Reduction of TOC & Hesnawi et al. (2014) \\
\hline 6. & \multicolumn{3}{|l|}{ Pseudomonas aeruginosa } \\
\hline 7. & $\begin{array}{c}\text { Methylobacterium } \\
\text { organophilum }\end{array}$ & Removal of $\mathrm{Cu}$ and $\mathrm{Pb}$ from wastewater & Kim et al. (1996) \\
\hline 8. & Herminiimonas arsenicoxydans & Arsenic absorption in wastewater & Marchal et al. (2010) \\
\hline
\end{tabular}

\subsection{Computational Fluid Dynamics in Wastewater}

Treatment

In recent years, computational fluid dynamics (CFD), a broadly used method, has been applied to biological wastewater treatment. It has exposed the inner flow state that is the hydraulic condition of a biological reactor (Peng et al., 2014). CFD is the application of powerful predictive modeling and simulation tools. It may calculate the multiple interactions between all the water quality and process design parameters. CFD modeling tools have already been widely used in other industries, but their application in the water industry is quite recent. CFD modeling has great applications in water and wastewater treatment, where it mechanically works by using hydrodynamic and mass transfer performance of single or twophase flow reactors (Do-Quang et al., 1998). The level of CFD's capability varies between different process units. It has a high frequency of application in the areas of final sedimentation, activated sludge basin modeling, disinfection, and greater needs in primary sedimentation and anaerobic digestion (Samstag et al., 2016). Now, researchers are enhancing the CFD modeling with a developed 3D model of the anoxic zone to evaluate further hydrodynamic performance (Elshaw et al., 2016). The overall conceptual framework and the applications of the computational approach in wastewater treatment are presented in Fig. 4. 
Fig. 4 A schematic showing the overall conceptual framework on which depicting the computational approach in wastewater treatment

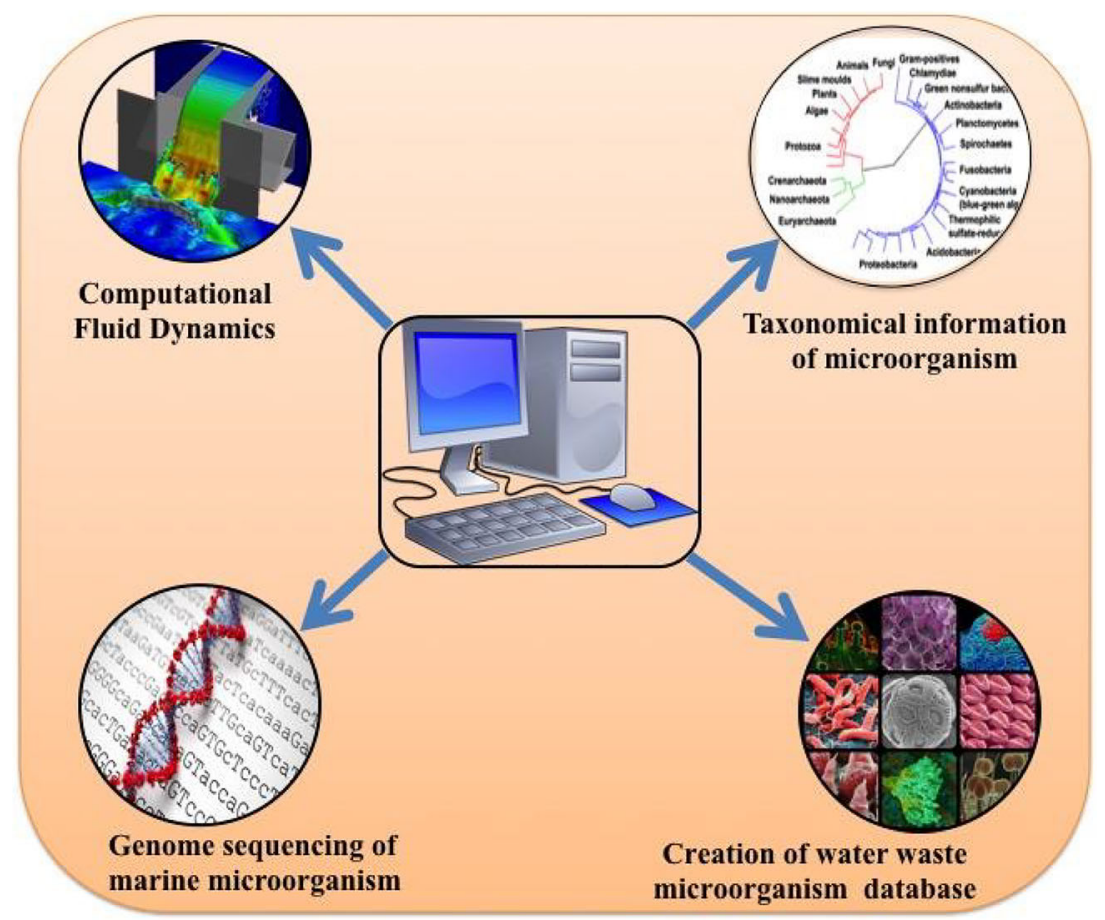

7.3 Computational Artificial Intelligence Approach in Wastewater Treatment

Several studies were obtained by researchers to implement computer-based artificial techniques, which provide fast and rapid automated monitoring of water quality tests such as BOD and COD. Recently, Nourani et al. (2018) explores the possibility of wastewater treatment plant by using three different kinds of artificial intelligence methods, i.e., feedforward neural network (FFNN), adaptive neuro-fuzzy inference system (ANFIS), and support vector machine (SVM). Several measurements were done in terms of effluent to tests BOD, COD, and total nitrogen in the Nicosia wastewater treatment plant (NWWTP) and reported highperformance efficiency of artificial intelligence (Nourani et al., 2018).

\subsection{Remote sensing and Geographical Information} System

Since the implementation of satellite technology, the initiation of new methods and tools became popular nowadays. The futuristic approach of remote sensing and GIS technology plays a crucial role in the identification and locating of the water polluted area through satellite imaginary and spatial data. GIS analysis may provide a quick and reasonable solution to develop atmospheric correction methods. Moreover, it provides a user-friendly environment, which may support complex spatial operations to get the best quality information on water quality parameters through remote sensing (Ramadas \& Samantaray, 2018).

\section{Applications of Treated Wastewater}

\subsection{Scope in Crop Irrigation}

Several studies have assessed the impact of the reuse of recycled/treated wastewater in major sectors. These are agriculture, landscapes, public parks, golf course irrigation, cooling water for power plants and oil refineries, processing water for mills, plants, toilet flushing, dust control, construction activities, concrete mixing, and artificial lakes (Table 5). Although the treated wastewater after secondary treatment is adequate for reuse since the level of heavy metals in the effluent is similar to that in nature (Ayers \& Westcot, 1985), experimental evidences have been found and evaluated the effects of irrigation with treated wastewater on soil fertility and chemical characteristics, where it has been 


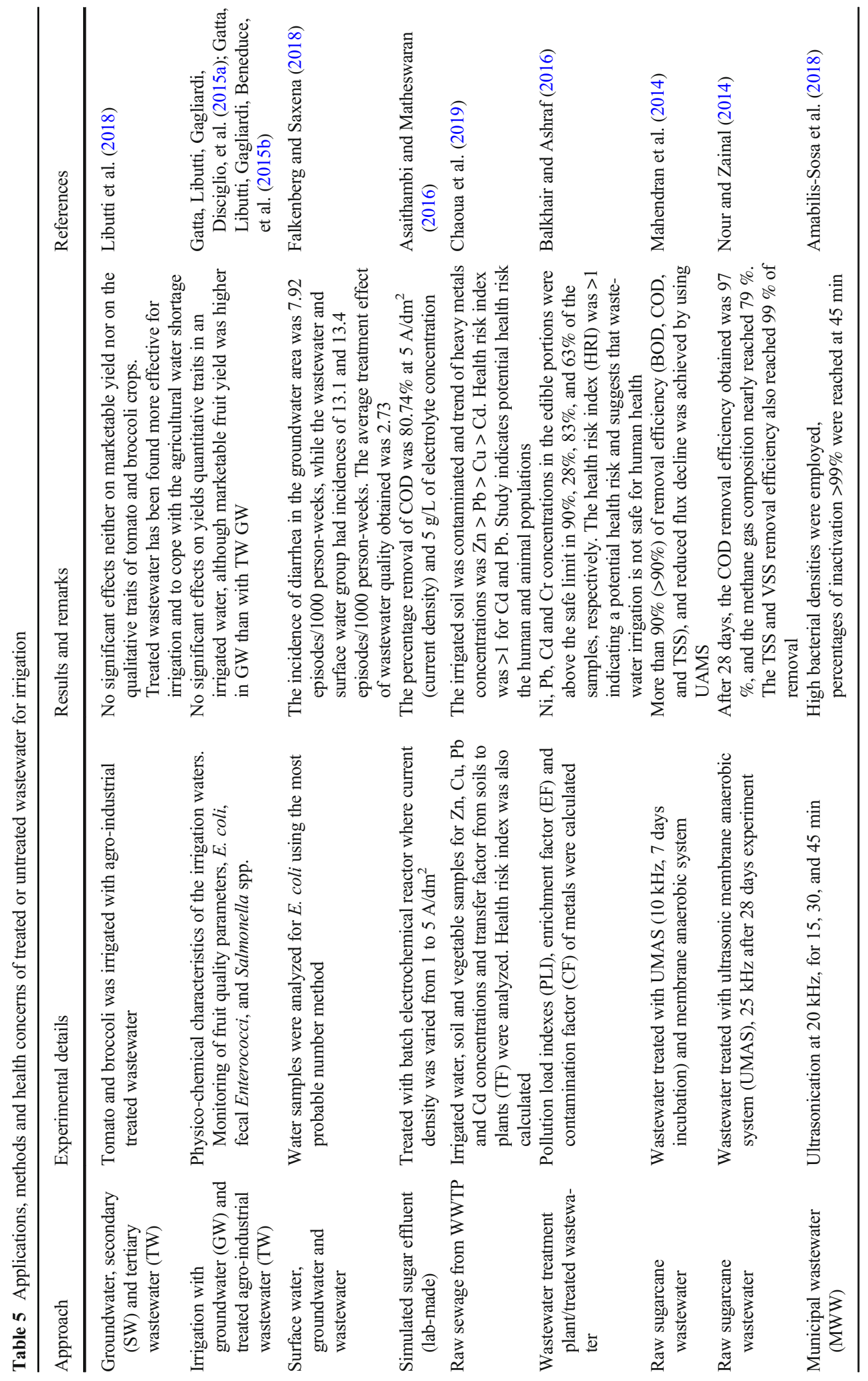




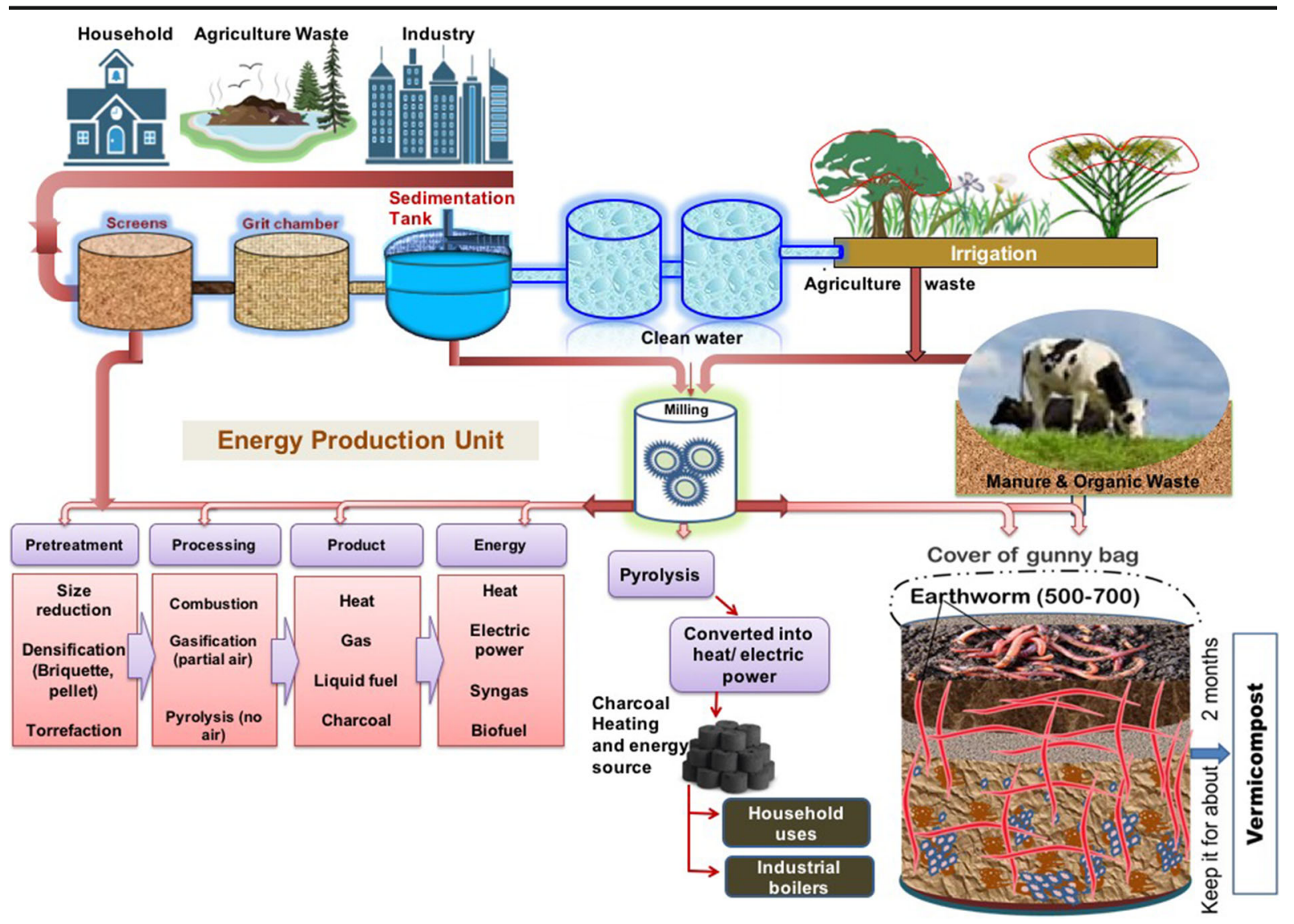

Fig. 5 Energy production through wastewater (reproduced from Bhatnagar et al., 2016; Kesari \& Jamal, 2017)

concluded that secondary treated wastewater can improve soil fertility parameters (Mohammad \& Mazahreh, 2003). The proposed model (Fig. 3) is tested partially previously at a laboratory scale by treating the wastewater (from sewage, sugar, and paper industry) in an ultrasonic bath (Kesari et al., 2011a, b; Kesari \& Behari, 2008; Kumar et al., 2010). Advancing it with ultraviolet and ozone treatment has modified this in the proposed model. A recent study shows that the treated water passed quality measures suited for crop irrigation (Bhatnagar et al., 2016). In Fig. 3, a model is proposed including all three (UV, US, nanoparticle, and ozone) techniques, which have been tested individually as well as in combination (US and nanoparticle) (Kesari et al., 2011a, b) to obtain the highest water quality standards acceptable for irrigation and even drinking purposes.

A wastewater-irrigated field is a major source of essential and non-essential metals contaminants such as lead, copper, zinc, boron, cobalt, chromium, arsenic, molybdenum, and manganese. While crops need some of these, the others are non-essential metals, toxic to plants, animals, and humans. Kanwar and Sandha (2000) reported that heavy metal concentrations in plants grown in wastewater-irrigated soils were significantly higher than in plants grown in the reference soil in their study. Yaqub et al. (2012) suggest that the use of US is very effective in removing heavy or toxic metals and organic pollutants from industrial wastewater. However, it has been also observed that the metals were removed efficiently, when UV light was combined with ozone (Samarghandi et al., 2007). Ozone exposure is a potent method for the removal of metal or toxic compounds from wastewater as also reported earlier (Park et al., 2008). Application of US, UV, and $\mathrm{O}_{3}$ in combination lead to the formation of reactive oxygen species (ROS) that oxidize certain organics, metal ions and kill pathogens. In the process of advanced oxidizing process (AOP) primarily oxidants, electricity, light, catalysts etc. are implied to produce extremely reactive free radicals 
(such as $\mathrm{OH}$ ) for the breakdown of organic matters (Oturan \& Aaron, 2014). Among the other AOPs, ozone oxidization process is more promising and effective for the decomposition of complex organic contaminants (Xu et al., 2020). Ozone oxidizes the heavy metal to their higher oxidation state to form metallic oxides or hydroxides in which they generally form limited soluble oxides and gets precipitated, which are easy to be filtered by filtration process. Ozone oxidization found to be efficient for the removal of heavy metals like cadmium, chromium, cobalt, copper, lead, manganese, nickel, and zinc from the water source (Upadhyay \& Srivastava, 2005). Ultrasonic-treated sludge leads to the disintegration of biological cells and kills bacteria in treated wastewater (Kesari, Kumar, et al., 2011a; Kesari, Verma, \& Behari, 2011b). This has been found that combined treatment with ultrasound and nanoparticles is more effective (Kesari, Kumar, et al., 2011a). Ultrasonication has the physical effects of cavitation inactivate and lyse bacteria (Broekman et al., 2010). The induced effect of US, US, or ozone may destroy the pathogens and especially during ultrasound irradiation including free-radical attack, hydroxyl radical attack, and physical disruption of cell membranes (Kesari, Kumar, et al., 2011a; Phull et al., 1997; Scherba et al., 1991).

\subsection{Energy and Economy Management}

Municipal wastewater treatment plants play a major role in wastewater sanitation and public health protection. However, domestic wastewater has been considered as a resource or valuable products instead of waste, because it has been playing a significant role in the recovery of energy and resource for the plant-fertilizing nutrients like phosphorus and nitrogen. Use of domestic wastewater is widely accepted for the crop irrigation in agriculture and industrial consumption to avoid the water crisis. It has also been found as a source of energy through the anaerobic conversion of the organic content of wastewater into methane gas. However, most of the wastewater treatment plants are using traditional technology, as anaerobic sludge digestion to treat wastewater, which results in more consumption of energy. Therefore, through these conventional technologies, only a fraction of the energy of wastewater has been captured. In order to solve these issues, the next generation of municipal wastewater treatment plants is approaching total retrieval of the energy potential of water and nutrients, mostly nitrogen and phosphorus. These plants also play an important role in the removal and recovery of emerging pollutants and valuable products of different nature like heavy and radioactive metals, fertilizers hormones, and pharma compounds. Moreover, there are still few possibilities of improvement in wastewater treatment plants to retrieve and reuse of these compounds. There are several methods under development to convert the organic matter into bioenergy such as biohydrogen, biodiesel, bioethanol, and microbial fuel cell. These methods are capable to produce electricity from wastewater but still need an appropriate development. Energy development through wastewater is a great driver to regulate the wastewater energy because it produces 10 times more energy than chemical, thermal, and hydraulic forms. Vermicomposting can be utilized for stabilization of sludge from the wastewater treatment plant. Kesari and Jamal (2017) have reported the significant, economical, and ecofriendly role of the vermicomposting method for the conversion of solid waste materials into organic fertilizers as presented in Fig. 5. Solid waste may come from several sources of municipal and industrial sludge, for example, textile industry, paper mill, sugarcane, pulp industry, dairy, and intensively housed livestock. These solid wastes or sewage sludges have been treated successfully by composting and/or vermicomposting (Contreras-Ramos et al., 2005; Elvira et al., 1998; Fraser-Quick, 2002; Ndegwa \& Thompson, 2001; Sinha et al., 2010) Although collection of solid wastes materials from sewage or wastewater and further drying is one of the important concerns, processing of dried municipal sewage sludge (Contreras-Ramos et al., 2005) and management (Ayilara et al., 2020) for vermicomposting could be possible way of generating organic fertilizers for future research. Vermicomposting of household solid wastes, agriculture wastes, or pulp and sugarcane industry wastes shows greater potential as fertilizer for higher crop yielding (Bhatnagar et al., 2016; Kesari \& Jamal, 2017). The higher amount of solid waste comes from agricultural land and instead of utilizing it, this biomass is processed by burning, which causes severe diseases (Kesari \& Jamal, 2017). Figure 3 shows the proper utilization of solid waste after removal from wastewater; however, Fig. 5 showing greater possibility in fertilizer conversion which has also been discussed in detail elsewhere (Bhatnagar et al., 2016; Nagavallemma et al., 2006) 


\section{Conclusions and future perspectives}

In this paper, we have reviewed environmental and public health issues associated with the use of untreated wastewater in agriculture. We have focused on the current state of affairs concerning the wastewater treatment model and computational approach. Given the dire need for holistic approaches for cultivation, we proposed the ideas to tackle the issues related to wastewater treatment and the reuse potential of the treated water. Water resources are under threat because of the growing population. Increasing generation of wastewater (municipal, industrial, and agricultural) in developing countries especially in India and other Asian countries has the potential to serve as an alternative of freshwater resources for reuse in rice agriculture, provide appropriate treatment, and distribution measures are adopted. Wastewater treatment is one of the big challenges for many countries because increasing levels of undesired or unknown pollutants are very harmful to health as well as environment. Therefore, this review explores the ideas based on current and future research. Wastewater treatment includes very traditional methods by following primary, secondary, and tertiary treatment procedures, but the implementation of advanced techniques is always giving us a big possibility of good water quality. In this paper, we have proposed combined methods for the wastewater treatment, where the concept of the proposed model works on the various types of wastewater effluents. The proposed model not only useful for wastewater treatment but also for the utilization of solid wastes as fertilizer. An appropriate method for the treatment of wastewater and further utilization for drinking water is the main futuristic outcome. It is also highly recommendable to follow the standard methods and available guidelines provided WHO. In this paper, the proposed role of the computational model, i.e., artificial intelligence, fluid dynamics, and GIS, in wastewater treatment could be useful in future studies. In this review, health concerns associated with wastewater irrigation for farmers and irrigated crops consumers have been discussed.

The crisis of freshwater is one of the growing concerns in the twenty-first century. Globaly, about $330 \mathrm{~km}^{3}$ of municipal wastewater is generated annually (Hernández-Sancho et al., 2015). This data provides a better understanding of why the reuse of treated wastewater is important to solve the issues of the water crisis. The use of treated wastewater (industrial or municipal wastewater or Seawater) for irrigation has a better future for the fulfillment of water demand. Currently, in developing countries, farmers are using wastewater directly for irrigation, which may cause several health issues for both farmers and consumers (crops or vegetables). Therefore, it is very imperative to implement standard and advanced methods for wastewater treatment. A local assessment of the environmental and health impacts of wastewater irrigation is required because most of the developed and developing countries are not using the proper guidelines. Therefore, it is highly required to establish concrete policies and practices to encourage safe water reuse to take advantage of all its potential benefits in agriculture and for farmers.

Acknowledgements All the authors are highly grateful to the authority of the respective departments and institutions for their support in doing this research. The author VT would like to thank Science \& Engineering Research Board, New Delhi, India (Grant \#ECR/2017/001809). The Author RS is thankful to the University Grants Commission for the National Fellowship (201819-NFO2018-19-OBC-UTT-78476).

Funding Open access funding provided by Aalto University.

\section{Declarations}

Conflict of Interest The authors declare that they have no conflict of interest.

Open Access This article is licensed under a Creative Commons Attribution 4.0 International License, which permits use, sharing, adaptation, distribution and reproduction in any medium or format, as long as you give appropriate credit to the original author(s) and the source, provide a link to the Creative Commons licence, and indicate if changes were made. The images or other third party material in this article are included in the article's Creative Commons licence, unless indicated otherwise in a credit line to the material. If material is not included in the article's Creative Commons licence and your intended use is not permitted by statutory regulation or exceeds the permitted use, you will need to obtain permission directly from the copyright holder. To view a copy of this licence, visit http://creativecommons.org/licenses/by/4.0/.

\section{References}

Abdel-Fatah, M. A. (2018). Nanofiltration systems and applications in wastewater treatment: Review article. Ain Shams Engineering Journal, 9, 3077-3092. 
Adegoke, A. A., Faleye, A. C., Singh, G., \& Stenström, T. A. (2016). Antibiotic resistant superbugs: Assessment of the interrelationship of occurrence in clinical settings and environmental niches. Molecules, 22, E29.

Adegoke, A. A., Stenström, T. A., \& Okoh, A. I. (2017). Stenotrophomonas maltophilia as an emerging ubiquitous pathogen: Looking beyond contemporary antibiotic therapy. Frontiers in Microbiology, 8, 2276.

Adegoke, A. A., Amoah, I. D., Stenström, T. A., Verbyla, M. E., \& Mihelcic, J. R. (2018). Epidemiological evidence and health risks associated with agricultural reuse of partially treated and untreated wastewater: A review. Frontiers in Public Health, 6, 337.

Adewumia, J. R., Ilemobadea, A. A., \& Vanzyl, J. E. (2010). Treated wastewater reuse in South Africa: Overview, potential, and challenges. Resources, Conservation and Recycling, 55, 221-231.

Agoro, M. A., Adeniji, A. O., Adefisoye, M. A., \& Okoh, O. O. (2020). Heavy metals in wastewater and sewage sludge from selected municipal treatment plants in Eastern Cape Province, South Africa. Water, 12, 2746.

Akasaka, T., \& Watari, F. (2009). Capture of bacteria by flexible carbon nanotubes. Acta Biomaterialia, 5, 607-612.

Akponikpe, P., Wima, K., Yakouba, H., \& Mermoud, A. (2011). Reuse of domestic wastewater treated in macrophyte ponds to irrigate tomato and eggplants in semi-arid West-Africa: Benefits and risks. Agricultural Water Management, 98, 834-840.

Alghobar, M. A., Ramachandra, L., \& Suresha, S. (2014). Effect of sewage water irrigation on soil properties and evaluation of the accumulation of elements in Grass crop in Mysore city, Karnataka, India. American Journal of Environmental Protection, 3, 283-291.

Al-Nakshabandi, G. A., Saqqar, M. M., Shatanawi, M. R., Fayyad, M., \& Al-Horani, H. (1997). Some environmental problems associated with the use of treated wastewater for irrigation in Jordan. Agricultural Water Management, 34, 81-94.

Amabilis-Sosa, L. E., Vázquez-López, E., García Rojas, J. L., Roé-Sosa, A., \& Moeller-Chávez, G. E. (2018). Efficient bacteria inactivation by ultrasound in municipal wastewater. Environments, 5, 47.

Amoah, I. D., Adegoke, A. A., \& Stenström, T. A. (2018). Soiltransmitted helminth infections associated with wastewater and sludge reuse: A review of current evidence. Tropical Medicine \& International Health, 23(7), 692-703.

Anastasi, A., Spina, F., Prigione, V., Tigini, V., Giansanti, P., \& Varese, G. C. (2010). Scale-up of a bioprocess for textile wastewater treatment using Bjerkandera adusta. Bioresource Technology, 101, 3067-3075.

Angelakis, A., \& Snyder, S. (2015). Wastewater treatment and reuse: Past, present, and future. Water, 7, 87-95.

Angelakis, A. N., Marecos do Monte, M. H. F., Bontoux, L., \& Asano, T. (1999). The status of wastewater reuse practice in the Mediterranean basin: Need for guidelines. Water Research, 33, 2201-2217.

Asaithambi, P., \& Matheswaran, M. (2016). Electrochemical treatment of simulated sugar industrial effluent: Optimization and modeling using a response surface methodology. Arabian Journal of Chemistry, 9, S981-S987.
Ayers, R. S., \& Westcot, D. W. (1985). Water quality for agriculture; Food and Agriculture Organization of the United. Nations.

Ayilara, M. S., Olanrewaju, O. S., Babalola, O. O., \& Odeyemi, O. (2020). Waste management through composting: Challenges and potentials. Sustainability, 12, 4456.

Azevedo, B. F., Furieri, L. B., Peçanha, F. M., Wiggers, G. A., Vassallo, P. F., Simões, M. R., et al. (2014). Toxic effects of mercury on the cardiovascular and central nervous systems. Journal of Preventive Medicine and Public Health, 47, 74-83.

Aziz, F., \& Farissi, M. (2014). Reuse of treated wastewater in agriculture: solving water deficit problems in arid areas. Annals of West University of Timişoara Series of Biology, $17,95-110$.

Balcom, I. N., Driscoll, H., Vincent, J., \& Leduc, M. (2016). Metagenomic analysis of an ecological wastewater treatment plant's microbial communities and their potential to metabolize pharmaceuticals. F1000 Research, 5, 1881.

Balkhair, K. S. (2016a). Microbial contamination of vegetable crop and soil profile in arid regions under controlled application of domestic wastewater. Saudi Journal of Biological Sciences, 23(1), S83-S92.

Balkhair, K. S. (2016b). Impact of treated wastewater on soil hydraulic properties and vegetable crop under irrigation with treated wastewater, field study and statistical analysis. Journal of Environmental Biology, 37(5), 1143-1152.

Balkhair, K. S., \& Ashraf, M. A. (2016). Field accumulation risks of heavy metals in soil and vegetable crop irrigated with sewage water in western region of Saudi Arabia. Saudi Journal of Biological Science, 23, S32-S44.

Behling, E., Diaz, A., Colina, G., Herrera, M., Gutierrez, E., Chacin, E., et al. (1996). Domestic wastewater treatment using a UASB reactor. Bioresource Technology, 61, 239245.

Bent, S., \& Bohm, K. (1995). Copper induced liver cirrhosis in a 13-month-old boy. Gesundheitswesen (health system in German), 57, 667-669.

Bhatnagar, A., Kesari, K. K., \& Shurpali, N. (2016). Multidisciplinary approaches to handling wastes in sugar industries. Water, Air, \& Soil Pollution, 11, 1-30.

Blume, T., \& Neis, U. (2004). Improved wastewater disinfection by ultrasonic pre-treatment. Ultrasonics Sonochemistry, 11, 333-336.

Bolong, N., Ismail, A. F., Salim, M. R., \& Matsuura, T. (2009). A review of the effects of emerging contaminants in wastewater and options for their removal. Desalination, 239, 229-246.

Bonefeld-Jorgensen, E. C., Long, M., Bossi, R., Ayotte, P., Asmund, G., Kruger, T., et al. (2011). Perfluorinated compounds are related to breast cancer risk in Greenlandic Inuit: A case control study. Environmental Health Perspectives, 10, 88-95.

Börjesson, S., Melin, S., Matussek, A., \& Lindgren, P. E. (2009). A seasonal study of the mecA gene and Staphylococcus aureus including methicillin-resistant $S$. aureus in a municipal wastewater treatment plant. Water Research, 43, 925-932.

Bos, R., Carr, R., \& Keraita, B. (2010). Assessing and mitigating wastewater-related health risks in low income countries: An introduction. In P. Drechsel, C. A. Scott, L. Raschid-Sally, M. Redwood, \& A. Bahri (Eds.), In: Wastewater irrigation 
and health: Assessing and mitigating risk in low-income countries (pp. 29-47). Earthscan.

Briffa, J., Sinagra, E., \& Blundell, R. (2020). Heavy metal pollution in the environment and their toxicological effects on humans. Heliyon, 6, e04691.

Brissaud, F. (2008). Criteria for water recycling and reuse in the Mediterranean countries. Desalination, 218, 24-33.

Broekman, S., Pohlmann, O., Beardwood, E. S., \& de Meulenaer, E. C. (2010). Ultrasonic treatment for microbiological control of water systems. Ultrasonics Sonochemistry, 17, 1041-1048.

Brumer, L. (2000). Use of aquatic macrophytes to improve the quality of effluents after chlorination. Ph.D. Dissertation, Technion Israel Institute of Technology, Haifa.

Busgang, A., Friedler, E., Gilboa, Y., \& Gross, A. (2018). Quantitative microbial risk analysis for various bacterial exposure scenarios involving greywater reuse for irrigation. Water, 10, 413.

Caplin, J. L., Hanlon, G. W., \& Taylor, H. D. (2008). Presence of vancomycin and ampicillin-resistant Enterococcus faecium of epidemic clonal complex-17 in wastewaters from the south coast of England. Environmental Microbiology, 10, 885-892.

Carey, C., Lee, H., \& Trevors, J. (2004). Biology, persistence and detection of Cryptosporidium parvum and Cryptosporidium homynis oocyst. Water Research, 38, 818-868.

Carr, R. (2005). WHO guidelines for safe wastewater use-more than just numbers. Irrigation and Drainage, 54, 103-111.

CCREM. (1987). Canadian Water Quality Guidelines. Prepared by the Task Force on Water Quality Guidelines of the Canadian Council of Resource and Environment Ministers.

Chang, J. S., Chou, C., \& Chen, S. Y. (2001). Decolorization of azo dyes with immobilized Pseudomonas luteola. Process Biochemistry, 36, 757-763.

Chaoua, S., Boussaa, S., Gharmali, A. E., \& Boumezzough, A. (2019). Impact of irrigation with wastewater on accumulation of heavy metals in soil and crops in the region of Marrakech in Morocco. Journal of the Saudi Society of Agricultural Sciences, 18, 429-436.

Chen, K., \& Pachter, L. (2005). Bioinformatics for whole-genome shotgun sequencing of microbial communities. PLoS Computational Biology, 1, 106-112.

Chen, W., Lu, S., Pan, N., \& Jiao, W. (2013). Impacts of long-term reclaimed water irrigation on soil salinity accumulation in urban green land in Beijing. Water Resources Research, 49, 7401-7410.

City of Cape Town (CoCT). 2007 Water services Development plan $2007 / 2008$. www.c a petown.gov. za/en/Water/WaterservicesDevPlan/Pages/WaterServDev Plan200708.aspx Accessed 12 June 2008.

Clemmens, A. J., Allen, R. G., \& Burt, C. M. (2008). Technical concepts related to conservation of irrigation and rainwater in agricultural systems. Water Resources Research, 44, 1-16.

Coleman, J., Hench, K., Garbutt, K., Sexstone, A., Bissonnette, B., \& Skousen, J. (2001). Treatment of domestic wastewater by three plant species in constructed wetlands. Water, Air, and Soil Pollution, 3, 283-295.

Contreras, J. D., Meza, R., Siebe, C., Rodríguez-Dozal, S., LópezVidal, Y. A., Castillo-Rojas, G., et al. (2017). Health risks from exposure to untreated wastewater used for irrigation in the Mezquital Valley, Mexico: A 25-year update. Water Research, 123, 834-850.

Contreras-Ramos, S. M., Escamilla-Silva, E. M., \& Dendooven, L. (2005). Vermicomposting of biosolids with cow manure and wheat straw. Biological Fertility of Soils, 41, 190-198.

Craun, M. F., Craun, G. F., Calderon, R. L., \& Beach, M. J. (2006). Waterborne outbreaks in the United States. Journal of Water and Health, 4(suppl 2), 19-30.

Craun, G. F., Brunkard, J. M., Yoder, J. S., Roberts, V. A., Carpenter, J., Wade, T., et al. (2010). Causes of outbreaks associated with drinking water in the United States from 1971 to 2006. Clinical Microbiology Reviews, 23, 507-528.

Dang, Q., Tan, W., Zhao, X., Li, D., Li, Y., Yang, T., et al. (2019). Linking the response of soil microbial community structure in soils to long-term wastewater irrigation and soil depth. The Science of the total environment, 688, 26-36.

Delgado, A., Anselmo, A. M., \& Novais, J. M. (1998). Heavy metal biosorption by dried powdered mycelium of Fusarium Flocci ferum. Water Environmental Research, 70, 370.

Dewitt, J. C., Peden-Adams, M. M., Keller, J. M., \& Germolec, D. R. (2012). Immunotoxicity of perfluorinated compounds: Recent developments. Toxicologic Pathology, 40, 300-311.

Dickin, S. K., Schuster-Wallace, C. J., Qadir, M., \& Pizzacalla, K. (2016). A review of health risks and pathways for exposure to wastewater use in agriculture. Environmental Health Perspectives, 124, 900-909.

Do-Quang, Z., Cockx, A., Line, A., \& Roustan, M. (1998). Computational fluid dynamics applied to water and wastewater treatment facility modeling. Environmental Engineering and Policy, 1, 137-147.

Drechsel, P., Scott, A., Sally, R., Redwood, M., Bachir, A. (2010). Wastewater Irrigation and Health: Assessing and Mitigating Risk in Low-Income Countries; International Water Management Institute, Ed.; Earthscan: London, UK.

Duan, J. J., Zhao, J. N., Xue, L. H., \& Yang, L. Z. (2016). Nutrient removal of a floating plant system receiving low- pollution wastewater: Effects of plant species and influent concentration. IOP Conference Series: Earth and Environmental Science, 41, 1.

Duan, B., Zhang, W., Zheng, H., Wu, C., Zhang, Q., \& Bu, Y. (2017). Comparison of health risk assessments of heavy metals and as in sewage sludge from wastewater treatment plants (WWTPs) for adults and children in the Urban district of Taiyuan, China. International Journal of Environmental Research and Public Health, 14, 1194.

Duncan, M. (2009). Waste stabilization ponds: Past, present and future. Desalination and Water Treatment, 4, 85-88.

Ecosse, D. (2001). Alternative techniques in order to meet the shortage of water in the world. Mem DESS Quality and Management of Water, Fac. Science, Amiens 62.

EEA CSI (2018). https://www.eea.europa.eu/themes/water/waterresources/water-use-by-sectors. Accessed 3 Oct 2019.

EPA (Environmental Protection Agency) (2002).National Recommended Water Quality Criteria: 2002. Office of Water, Office of Science and Technology. EPA-822-R-02047.

Elshaw, A., Hassan, N. M. S., Khan, M. M. K. (2016). CFD modelling and optimisation of a wastewater treatment plant bioreactor-A case study. In Proceedings of the 2016 3rd Asia-Pacific World Congress on Computer science and 
Engineering (APWC on CSE), 232-239 https://doi. org/10.1109/APWC-on-CSE.2016.046.

Elvira, C., Sampedro, L., Benitez, E., \& Nogales, R. (1998). Vermicomposting of sludges from paper mills and dairy industries with Elsenia anderi. A pilot scale study. Journal of Bioresource Technology, 63, 205-211.

Falkenberg, T., \& Saxena, D. (2018). Impact of wastewaterirrigated urban agriculture on diarrhea incidence in Ahmedabad, India. Indian Journal of Community Medicine, 43, 102-106.

FAO, (1985) Water Quality for Agriculture. Irrigation and Drainage Paper No. 29, Rev. 1. Food and Agriculture Organization of the United Nations, Rome.

Fazeli, M. S., Khosravan, F., Hossini, M., Sathyanarayan, S., \& Satish, P. N. (1998). Enrichment of heavy metals in paddy crops irrigated by paper mill effluents near Nanjangud, Mysore District, Karnataka, India. Environmental Geology, 34, 297-302.

FEPA. (1991). Proposed National Water Quality Standards. Federal Environmental Protection Agency.

Foerstner, K. U., Von-Mering, C., \& Bork, P. (2006). Comparative analysis of environmental sequences: potential and challenges. Philosophical transactions of the Royal Society of London Series B, Biological sciences, $361,519-523$.

Founou, R. C., Founou, L. L., \& Essack, S. Y. (2017). Clinical and economic impact of antibiotic resistance in developing countries: A systematic review and meta-analysis. PLoS One, 12, e0189621. https://doi.org/10.1371/journal.pone.0189621.

Fraser-Quick, G. (2002). Vermiculture - A sustainable total waste management solution. What's New in Waste Management?, 4, 13-16.

Freitas, F., Alves, V. D., Pais, J., Costa, N., Oliveira, C., \& Mafra, L. (2009). Characterization of an extracellular polysaccharide produced by a Pseudomonas strain grown on glycerol. Bioresource Technology, 100, 859-865.

Freitas, F., Alves, V. D., \& Reis, M. A. (2011a). Advances in bacterial exopolysaccharides: From production to biotechnological applications. Trends in Biotechnology, 29, 388-398.

Freitas, F., Alves, V. D., Torres, C. A., Cruz, M., Sousa, I., \& Melo, M. J. (2011b). Fucose-containing exopolysaccharide produced by the newly isolated Enterobacter strain A47 DSM 23139. Carbohydrate Polymers, 83, 159-165.

Frontistis, Z., Xekoukoulotakis, N. P., Hapeshi, E., Venieri, D., Fatta-Kassinos, D., \& Mantzavinos, D. (2011). Fast degradation of estrogen hormones in environmental matrices by photo-Fenton oxidation under simulated solar radiation. Chemical Engineering Journal, 178(15), 175-182.

Fukushima, M., Ishizaki, A., \& Sakamoto, M. (1970). On distribution of heavy metals in rice field soil in the "Itai-itai" disease epidemic district. Japanese Journal of Hygiene, 24, $526-535$

Gatta, G., Libutti, A., Gagliardi, A., Disciglio, G., Beneduce, L., d'Antuono, M., Rendina, M., \& Tarantino, E. (2015a). Effects of treated agro-industrial wastewater irrigation on tomato processing quality. Italian Journal of Agronomy, 10(2), 97-100.

Gatta, G., Libutti, A., Gagliardi, A., Beneduce, L., Borruso, L., Disciglio, G., \& Tarantino, G. (2015b). Treated agroindustrial wastewater irrigation of tomato crop: Effects on qualitative/quantitative characteristics of production and microbiological properties of the soil. Agricultural Water Management, 149, 33-43.

Gehrke, I., Geiser, A., \& Somborn-Schulz, A. (2015). Innovations in nanotechnology for water treatment. Nanotechnology, Science and Applications, 8, 1-17.

Genchi, G., Sinicropi, M. S., Lauria, G., Carocci, A., \& Catalano, A. (2020). The effects of cadmium toxicity. International Journal of Environmental Research and Public Health, 17, 3782.

Giddins, M. J., Macesic, N., Annavajhala, M. K., Stump, S., Khan, S., McConville, T. H., Mehta, M., Gomez-Simmonds, A., \& Uhlemann, A. C. (2017). Successive emergence of ceftazidime-avibactam resistance through distinct genomic adaptations in bla(KPC-2)-harboring Klebsiella pneumoniae sequence type 307 isolates. Antimicrobial Agents and Chemotherapy, 62, e02101-e02117.

Goel, J., Kadirvelu, K., Rajagopal, C., Kumar, G., \& V. (2005). Removal of lead (II) by adsorption using treated granular activated carbon: Batch and column studies. Journal of Hazardous Materials, 125(1-3), 211-220.

Goldstein, R. E. R. (2013). Antibiotic-resistant bacteria in wastewater and potential human exposure through wastewater reuse. $\mathrm{PhD}$ Dissertation, University of Maryland.

Gupta, P., \& Diwan, B. (2017). Bacterial Exopolysaccharide mediated heavy metal removal: A review on biosynthesis, mechanism and remediation strategies. Biotechnology Reports, 13, 58-71.

Gupta, S. K., Shin, H., Han, D., Hur, H. G., \& Unno, T. (2018). Metagenomic analysis reveals the prevalence and persistence of antibiotic- and heavy metal-resistance genes in wastewater treatment. Plant Journal of Microbiology, 56, 408-415.

GWI Global Water Intelligence. (2009). PUB study: Perspectives of water reuse. GWI Publishing.

Hall, N. (2007). Advanced sequencing technologies and their wider impact in microbiology. Journal of Experimental Biology, 210, 1518-1525.

Halliwell, D. J., Barlow, K. M., \& Nash, D. M. (2001). A review of the effects of wastewater sodium on soil physical properties and their implications for irrigation systems. Australian Journal of Soil Research, 39, 1259-1267.

He, Y., Yuan, Q., Mathieu, J., Stadler, L., Senehi, N., Sun, R., \& Alvarez, P. J. J. (2020). Antibiotic resistance genes from livestock waste: Occurrence, dissemination and treatment. npj Clean Water, 3, 4.

Herc, E. S., Kauffman, C. A., Marini, B. L., Perissinotti, A. J., \& Miceli, M. H. (2017). Daptomycin nonsusceptible vancomycin resistant Enterococcus bloodstream infections in patients with hematological malignancies: Risk factors and outcomes. Leukemia \& Lymphoma, 58, 2852-2858.

Hernández-Sancho, F., Lamizana-Diallo, B., Mateo-Sagasta, J., \& Qadeer, M. (2015). Economic valuation of wastewater-The cost of action and the cost of no action. United Nations Environment Programme.

Hesnawi, R., Dahmani, K., Al-Swayah, A., Mohamed, S., \& Mohammed, S. A. (2014). Biodegradation of municipal wastewater with local and commercial bacteria. Procedia Engineering, 70, 810-814.

Hoekstra, A. Y., \& Mekonnen, M. M. (2012). The water footprint of humanity. Proceedings of the National Academy of Sciences, 109, 3232-3237. 
Hua, I., \& Thompson, J. E. (2000). Inactivation of E. coli by sonication at discrete ultrasonic frequencies. Water Research, 34, 3888-3893.

Hussain, A., Priyadarshi, M., \& Dubey, S. (2019). Experimental study on accumulation of heavy metals in vegetables irrigated with treated wastewater. Applied Water Science, 9, 122.

Icgen, B., \& Yilmaz, F. (2014). Co-occurrence of antibiotic and heavy metal resistance in Kizilirmak River isolates. Bulletin of Environmental Contamination and Toxicology, 93, 735743.

Iguchi, S., Mizutani, T., Hiramatsu, K., \& Kikuchi, K. (2016). Rapid acquisition of linezolid resistance in methicillinresistant Staphylococcus aureus: Role of hypermutation and homologous recombination. PLoS One, 11, e 0155512.

Indiana State Department of Health, 2009. Diseases Involving Sewage. https://www.in.gov/isdh/22963.htm

Inoue, Y., Hoshino, M., Takahashi, H., Noguchi, T., Murata, T., \& Kanzaki, Y. (2002). Bactericidal activity of Ag-zeolite mediated by reactive oxygen species under aerated conditions. Journal of Inorganic Biochemistry, 92, 37-42.

Jacquez, R. B., Walner, H. Z. (1985). Combining nutrient removal with protein synthesis using a water hyacinth-freshwater prawn polyculture wastewater treatment system. New Mexico Water Resources Research Institute. 92.

Jaishankar, M., Tseten, T., Anbalagan, N., Mathew, B. B., \& Beeregowda, K. N. (2014). Toxicity, mechanism and health effects of some heavy metals. Interdisciplinary Toxicology, $7(2), 60-72$.

Jarup, L. (2003). Hazards of heavy metal contamination. British Medical Bulletin, 68, 167-182.

Jeong, H., Kim, H., \& Jang, J. (2016). Irrigation water quality standards for indirect wastewater reuse in agriculture: A contribution toward sustainable wastewater reuse in South Korea. Water, 8, 169.

Jia, S., Zhang, X. (2020). Biological HRPs in wastewater. In High-risk pollutants in wastewater. Eds. Ren, H. and Zhang, X. 41-67.

Jiménez, B., \& Asano, T. (2008). Water reclamation and reuse around the world. In B. Jiménez \& T. Asano (Eds.), In: Water reuse: An International Survey of Current Practice, Issues and Needs (pp. 3-26). IWA Publishing.

Jindal, A., Kamat, S. (2011). Water recycling and reuse for domestic and industrial sectors. Chemical Engineering World, 52-62.

Jyothi, N.R. (2020). Heavy metal sources and their effects on human health, heavy metals - Their environmental impacts and mitigation. Ed. Nazal, M. 95370.

Jyothi, N.R. and Farook, N.A.M. (2020). Mercury toxicity in public health, Heavy Metal Toxicity in Public Health. 1-12.

Jyoti, K. K., \& Pandit, A. B. (2004). Ozone and cavitation for water disinfection. Biochemical Engineering Journal, 38, 2249-2258.

Kalavrouziotis, I. K., Kokkinos, P., Oron, G., Fatone, F., Bolzonella, D., Vatyliotou, M., et al. (2015). Current status in wastewater treatment, reuse and research in some mediterranean countries. Desalination and Water Treatment, 53, 2015-2030.

Kanwar, J., \& Sandha, M. (2000). Waste water pollution injury to vegetable crops: A review. Agricultural Research Communication Centre, India, 21, 133-136.
Katsoyiannis, I. A., Gkotsis, P., Castellana, M., Cartechini, F., \& Zouboulis, A. I. (2017). Production of demineralized water for use in thermal power stations by advanced treatment of secondary wastewater effluent. Journal of Environmental Management, 1(190), 132-139.

Kenny, J. F., Barber, N. L., Hutson, S. S., Linsey, K. S., Lovelace, J. K., \& Maupin, M. A. (2009). Estimated use of water in the United States in 2005. U.S. Geological Survey Circular, 1344, 52.

Kesari, K. K., \& Behari, J. (2008). Ultrasonic impact on bacterial population in sewage sample. International Journal of Environment and Waste Management, 2, 233-244.

Kesari, K. K., Jamal, Q. M. S. (2017). Review Processing, properties and applications of agricultural solid waste: Effect of an open burning in environmental toxicology. In: Kesari K. (eds) Perspectives in Environmental Toxicology. Environmental Science and Engineering. Springer, Cham. Chapter 8:161-181.

Kesari, K. K., Kumar, S., Verma, H. N., \& Behari, J. (2011a). Influence of ultrasonic treatment in sewage sludge. Hydrology: Current Research, 2, 115.

Kesari, K. K., Verma, H. N., \& Behari, J. (2011b). Physical methods in wastewater treatment. International Journal of Environmental Technology and Management, 14, 43-66.

Khaskhoussy, K., Kahlaoui, B., Messoudi, N. B., Jozdan, O., Dakheel, A., \& Hachicha, M. (2015). Effect of treated wastewater irrigation on heavy metals distribution in a Tunisian soil. Engineering Technology and Applied Science Research, 5, 805-810.

Kim, S. Y., Kim, J. H., Kim, C. J., \& Oh, D. K. (1996). Metal adsorption of the polysaccharide produced from Methylobacterium organophilum. Biotechnology Letters, 18, 1161-1164.

Kim, B. H., Kang, Z., Ramanan, R., Choi, J. E., Cho, D. H., Oh, H. M., et al. (2014). Nutrient removal and biofuel production in high rate algal pond using real municipal wastewater. Journal of Microbiology and Biotechnology, 24, 1123-1132.

Kinuthia, G. K., Ngure, V., Beti, D., Lugalia, R., Wangila, A., \& Kamau, L. (2020). Levels of heavy metals in wastewater and soil samples from open drainage channels in Nairobi, Kenya: community health implication. Scientific Reports, 10, 8434.

Kocabas, Z. O., Aciksoz, B., Yurum, Y. (2012). Binding mechanisms of As(III) on activated carbon/titanium dioxide nanocomposites: a potential method for arsenic removal from water, MRS online proceedings library. Published online by Cambridge University Press 1449.

König, M., Escher, B. I., Neale, P. A., Krauss, M., Hilscherová, K., Novák, J., et al. (2017). Impact of untreated wastewater on a major European river evaluated with a combination of in vitro bioassays and chemical analysis. Environmental Pollution, 220(Part B), 1220-1230.

Kumar, R., \& Chawla, J. (2014). Removal of cadmium ion from water/wastewater by nano-metal oxides. Water Quality Exposure and Health, 5, 4.

Kumar, M., Kesari, K. K., \& Behari, J. (2010). Low frequency ultrasonic irradiation of activated sludge. International Journal of Environment and Pollution, 43, 52-65.

Kumar, S. S., Shantkriti, S., Muruganandham, T., Murugesh, E., Rane, N., \& Govindwar, N. P. (2016). Bioinformatics aided microbial approach for bioremediation of wastewater containing textile dyes. Ecological Informatics, 31, 112-121. 
Kumar, A., Ali, M., Kumar, R., Kumar, M., Sagar, P., Pandey, R. K., et al. (2021). Arsenic exposure in Indo Gangetic plains of Bihar causing increased cancer risk. Scientific Reports, 11, 2376.

Leddy, M. B., Plumlee, M. H., Kantor, R. S., Nelson, K. L., Miller, S. E., Kennedy, L. C., et al. (2018). High-throughput DNA sequencing to profile microbial water quality of potable reuse. Water online, 1-4.

Lee, I., \& Viberg, H. (2013). A single neonatal exposure to perfluorohexane sulfonate (PFHxS) affects the levels of important neuroproteins in the developing mouse brain. Neurotoxicology, 37, 190-196.

Libutti, A., Gatta, G., Gagliardi, A., Vergine, P., Pollice, A., Beneduce, L., Disciglio, G., \& Tarantino, E. (2018). Agroindustrial wastewater reuse for irrigation of a vegetable crop succession under Mediterranean conditions. Agricultural Water Management, 196, 1-14.

Liu, J., Ma, Y., Xu, T., \& Shao, G. (2010). Preparation of zwitterionic hybrid polymer and its application for the removal of heavy metal ions from water. Journal of Hazardous Materials, 178, 1021-1029.

Lv, L., Yu, X., Xu, Q., \& Ye, C. (2015). Induction of bacterial antibiotic resistance by mutagenic halogenated nitrogenous disinfection byproducts. Environmental Pollution, 205, 291-298.

Madsen, H., Poultsen, L., \& Grandjean, P. (1990). Risk of high copper content in drinking water. Ugeskr Laeger (Journal of the Danish Medical Association), 152(25), 1806-1809.

Mahendran, R., Ramli, N. H., \& Abdurrahman, H. N. (2014). Study the effect of using ultrasonic membrane anaerobic system in treating sugarcane waste and methane gas production. International Journal of Research in Engineering and Technology, 3, 299-303.

Mahfooz, Y., Yasar, A., Guijian, L., Islam, Q. U., Akhtar, A. B. T., Rasheed, R., Irshad, S., \& Naeem, U. (2020). Critical risk analysis of metals toxicity in wastewater irrigated soil and crops: a study of a semi-arid developing region. Scientific Reports, 10, 12845.

Mahmood, A., \& Malik, R. N. (2014). Human health risk assessment of heavy metals via consumption of contaminated vegetables collected from different irrigation sources in Lahore. Pakistan, Arabian Journal of Chemistry, 7(1), 9199.

Mañas, P., Castro, E., \& Heras, J. (2009). Irrigation with treated wastewater: effects on soil, lettuce (Lactuca sativa L.) crop and dynamics of microorganisms. Journal of Environmental Science and Health, 44, 1261.

Marchal, M., Briandet, R., Koechler, S., Kammerer, B., \& Bertin, P. N. (2010). Effect of arsenite on swimming motility delays surface colonization in Herminiimona sarsenicoxydans. Microbiology, 156, 2336-2342.

Marcussen, H., Holm, P. E., Ha, L. T., \& Dalsgaard, A. (2007). Food safety aspects of toxic element accumulation in fish from wastewater-feed ponds in Hanoi, Vietnam. Tropical Medicine \& International Health, 12, 34-39.

Marsh, S. (2007). Pyrosequencing applications. Methods in Molecular Biology, 373, 15-24.

Meehan, C., Bjourson, A. J., \& McMullan, G. (2001). Paeni bacillus azoreducens sp. nov., a synthetic azo dye decolorizing bacterium from industrial wastewater. International
Journal of Systematic and Evolutionary Microbiology, 51, 1681-1685.

Mehmood, A., Mirza, A. S., Choudhary, M. A., Kim, K. H., Raza, W., Raza, N., Lee, S. S., Zhang, M., Lee, J. H., \& Sarfraz, M. (2019). Spatial distribution of heavy metals in crops in a wastewater irrigated zone and health risk assessment. Environmental Research, 168, 382-388.

Melanta, S. (2008). Aquatic bacteria removal using carbon nanotubes. Biological and Agricultural Engineering Undergraduate Thesis. University of Arkansas.

Mohammad, M., \& Mazahreh, N. (2003). Changes in soil fertility parameters in response to irrigation of forage crops with secondary treated wastewater. Communications in Soil Science and Plant Analysis, 34, 181-1294.

Mohammad, A. W., Teow, Y. H., Ang, W. L., Chung, Y. T., Oatley-Radcliffe, D. L., \& Hila, N. (2015). Nanofiltration membranes review: Recent advances and future prospects. Desalination, 356, 226-254.

Mohsen, M. S. (2004). Treatment and reuse of industrial effluents: Case study of a thermal power plant. Desalination, 167, 7586.

Mostafaii, G., Chimehi, E., Gilasi, H. R., \& Iranshahi, L. (2017). Investigation of zinc oxide nanoparticles effects on removal of total coliform bacteria in activated sludge process effluent of municipal wastewater. Journal of Environmental Science and Technology, 1, 49-55.

Naddeo, V., Belgiorno, V., Ricco, D., \& Kassinos, D. (2009). Degradation of diclofenac by sonolysis, ozonation and their simultaneous application. Ultrasonics Sonochemistry, 16, 790-794.

Nagavallemma, K. P., Wani, S. P., Lacroix, S., Padmaja, V. V., Vineela, C., Babu, R. M., \& Sahrawat, K. L. (2006). Vermicomposting: recycling wastes into valuable organic fertilizer. SAT eJournal, 2, 1-16.

Narain, D. M., Bartholomeus, R. P., Dekker, S. C., \& Van Wezel, A. P. (2020). Natural purification through soils: Risks and opportunities of sewage effluent reuse in sub-surface irrigation. In In: Reviews of Environmental Contamination and Toxicology (Continuation of Residue Reviews) (pp. 1-33). Springer. https://doi.org/10.1007/398_2020_49.

Naylor, N. R., Atun, R., Zhu, N., Kulasabanathan, K., Silva, S., Chatterjee, A., Knight, G. M., \& Robotham, J. V. (2018). Estimating the burden of antimicrobial resistance: a systematic literature review. Antimicrobial Resistance and Infection Control, 7, 58.

Ndegwa, P. M., \& Thompson, S. A. (2001). Integrated composting and vermicomposting in the treatment and bioconversion of biosolids. Bioresource Technology, 76, 107-112.

Nizam, N. U. M., Hanafiah, M. M., Noor, I. M., \& Karim, H. I. A. (2020). Efficiency of five selected aquatic plants in phytoremediation of aquaculture wastewater. Applied Sciences, 10, 2712.

Njuguna, S. M., Makokha, V. A., Yan, X., Gituru, R. W., Wang, Q., \& Wang, J. (2019). Health risk assessment by consumption of vegetables irrigated with reclaimed wastewater: A case study in Thika (Kenya). Journal of Environmental Management, 231, 576-581.

Nmaya, M. M., Agam, M. A., Matias-Peralta, H. M., Yabagi, J. A., \& Kimpa, M. I. (2017). Freshwater green microalga for bioremediation of river melaka heavy metals contamination. Journal of Science and Technology, 9, 118-123. 
Nour, A. H., \& Zainal, Z. (2014). Membrane fouling control by ultrasonic membrane anaerobic system (UMAS) to produce methane gas. International Journal of Engineering Science Research Technology, 3, 487-497.

Nourani, V., Elkiran, G., \& Abba, S. I. (2018). Wastewater treatment plant performance analysis using artificial intelligence An ensemble approach. Water Science and Technology, 78(10), 2064-2076.

Numberger, D., Ganzert, L., Zoccarato, L., Mühldorfer, K., Sauer, S., \& Grossart, H. P. (2019). Characterization of bacterial communities in wastewater with enhanced taxonomic resolution by full-length $16 \mathrm{~S}$ rRNA sequencing. Scientific Reports, 9, 9673.

Odigie, J. O. (2014). Harmful effects of wastewater disposal into water bodies: A case review of the Ikpoba river, Benin city, Nigeria. Tropical Freshwater Biology, 23, 87-101.

Oilgae Guide to Algae-based Wastewater Treatment. (2014). Commonly used algae strains for wastewater treatment. http://www.oilgae.com/blog/2014/01/commonly-usedalgae-strains-for-waste-water-treatment.html. Accessed 5 May 2021

Okoh, A. I., Sibanda, T., \& Gusha, S. S. (2010). Inadequately treated wastewater as a source of human enteric viruses in the environment. International Journal of Environmental Research and Public Health, 7, 2620-2637.

Oturan, M. A., \& Aaron, J. J. (2014). Advanced oxidation processes in water/wastewater treatment: Principles and applications. A review. Critical Reviews in Environmental Science and Technology, 44, 2577-2641.

Paleologou, A., Marakas, H., Xekoukoulotakis, N. P., Moya, A., Vergara, Y., Kalogerakis, N., Gikas, P., \& Mantzavinos, D. (2007). Disinfection of water and wastewater by $\mathrm{TiO} 2$ photocatalysis, sonolysis and UV-C irradiation. Catalysis Today, 129, 136-142.

Pan, B., \& Xing, B. S. (2008). Adsorption mechanisms of organic chemicals on carbon nanotubes. Environmental Science and Technology, 42, 9005-9013.

Panthi, S., Sapkota, A. R., Raspanti, G., Allard, S. M., Bui, A., Craddock, H. A., Murray, R., et al. (2019). Pharmaceuticals, herbicides, and disinfectants in agricultural water sources. Environmental Research, 174, 1-8.

Park, K. Y., Maeng, S. K., Song, K. G., \& Ahn, K. H. (2008). Ozone treatment of wastewater sludge for reduction and stabilization. Journal Environmental Science Health. Part A, Toxic/Hazardous Substances \& Environmental Engineering, 43, 1546-1550.

Pedrero, F., Kalavrouziotis, I., Alarcón, J. J., Koukoulakis, P., \& Asano, T. (2010). Use of treated municipal wastewater in irrigated agriculture. Review of some practices in Spain and Greece. Agricultural Water Management, 97, 1233-1241.

Peng, S. M., Chen, Y. D., Guo, W. Q., Yang, S. S., Wu, Q. L., Luo, H. C., \& Ren, N. Q. (2014). The Application of computational fluid dynamics (CFD) in wastewater biological treatment field. Applied Mechanics and Materials, 507, 711-715.

Pesoutova, R., Hlavinek, P., \& Matysikova, J. (2011). Use of advanced oxidation processes for textile wastewater treatment- A review. Food and Environmental Safety, 10, 59-65.

Petrier, C., Jeunet, A., Luche, J. L., \& Reverdy, G. (1992). Unexpected frequency effects on the rate of oxidative processes induced by ultrasound. Journal of the American Chemical Society, 25, 148-3150.

Pham-Duc, P., Nguyen-Viet, H., Hattendorf, J., et al. (2014). Diarrhoeal diseases among adult population in an agricultural community Hanam province, Vietnam, with high wastewater and excreta reuse. BMC Public Health, 14, 978.

Phull, S. S., Newman, A. P., Lorimer, J. P., Pollet, T. J., \& Mason, T. J. (1997). The development and evaluation of ultrasound in the biocidal treatment of water. Ultrasonics Sonochemistry, 4, 157-164.

Poustie, A., Yang, Y., Verburg, P., Pagilla, K., \& Hanigan, D. (2020). Reclaimed wastewater as a viable water source for agricultural irrigation: A review of food crop growth inhibition and promotion in the context of environmental change. Science of the Total Environment, 739, 139756.

Punshon, T., Jackson, B. P., Meharg, A. A., Warczack, T., Scheckel, K., \& Guerinot, M. L. (2017). Understanding arsenic dynamics in agronomic systems to predict and prevent uptake by crop plants. Science of the Total Environment, 581-582, 209-220.

Puzas, J. E., Campbell, J., O’Keefe, R. J., \& Rosier, R. N. (2004). Lead toxicity in the skeleton and its role in osteoporosis. In Nutrition and Bone Health (pp. 373-376). Humana Press.

Qadir, M., Wichelns, D., Raschid-Sally, L., McCornick, P. G., Drechsel, P., Bahri, A., et al. (2010). The challenges of wastewater irrigation in developing countries. Agricultural Water Management, 97, 561-568.

Raes, J., Foerstner, K. U., \& Bork, P. (2007). Get the most out of your metagenome: Computational analysis of environmental sequence data. Current Opinion in Microbiology, 10, 490-498.

Ramadas, M., \& Samantaray, A. K. (2018). Applications of remote sensing and GIS in water quality monitoring and remediation: A state-of-the-art review. In S. Bhattacharya, A. Gupta, A. Gupta, \& A. Pandey (Eds.), Water remediation. Energy, Environment, and Sustainability. Springer.

Rizvi, H., Ahmad, N., Abbas, F., Bukhari, I. H., Yasar, A., Ali, S., Yasmeen, T., \& Riaz, M. (2015). Start-up of UASB reactors treating municipal wastewater and effect of temperature/ sludge age and hydraulic retention time (HRT) on its performance. Arabian Journal of Chemistry, 8, 780-786.

Russ, R., Rau, J., \& Stolz, A. (2000). The function of cytoplasmic flavin reductases in the reduction of azodyes by bacteria. Applied and Environmental Microbiology, 66, 1429-1434.

Sacks, M., \& Bernstein, N. (2011). Utilization of reclaimed wastewater for irrigation of field-grown melons by surface and subsurface drip irrigation. Israel Journal of Plant Sciences, 59, 159-169.

Sağ, Y. (2001). Biosorption of heavy metals by fungal biomass and modeling of fungal biosorption: A review. Separation and Purification Reviews, 30, 1-48.

Salem, H. M., Eweida, E. A., \& Farag, A. (2000). Heavy metals in drinking water and their environmental impact on human health (pp. 542-556). ICEHM.

Samarghandi, M. R., Nouri, J., Mesdaghinia, A. R., Mahvi, A. H., Nasseri, S., \& Vaezi, F. (2007). Efficiency removal of phenol, lead and cadmium by means of UV/TiO2/H2O2 processes. International journal of Environmental Science and Technology, 4, 19-25.

Samie, A., Obi, L., Igumbor, O., \& Momba, B. (2009). Focus on 14 sewage treatment plants in the Mpumalanga province, 
South Africa in order to gauge the efficiency of wastewater treatment. African Journal of Microbiology Research, 8, $3276-3285$.

Samstag, R. W., Ducoste, J. J., Griborio, A., Nopens, I., Batstone, D. J., Wicks, J., \& Laurent, J. (2016). CFD for wastewater treatment: An overview. Water Science and Technology, 74, 549-563.

Santajit, S., \& Indrawattana, N. (2016). Mechanisms of antimicrobial resistance in ESKAPE pathogens. BioMed Research International, 2016, 2475067.

Sato, T., Qadir, M., Yamamoto, S., Endo, T., \& Zahoor, A. (2013). Global, regional, and country level need for data on wastewater generation, treatment, and use. Agricultural Water Management, 130, 1-13.

Scherba, G., Weigel, R. M., \& Obrien, W. D. (1991). Quantitative assessment of the germicidal efficacy of ultrasonic energy. Applied and Environmental Microbiology, 57, 2079-2084.

Schloss, P. D., \& Handelsman, J. (2005). Metagenomics for studying unculturable microorganisms: Cutting the Gordian knot. Genome Biology, 6, 229.

Schmeisser, C., Steele, H., \& Streit, W. R. (2007). Metagenomics, biotechnology with non-culturable microbes. Applied Microbiology and Biotechnology, 75, 955-962.

Scott, C. A., Faruqui, N. I., \& Raschid-Sally, L. (2004). Wastewater use in irrigated agriculture: Management challenges in developing countries. In C. A. Scott, N. I. Faruqui, \& L. Raschid-Sally (Eds.), Wastewater use in irrigated agriculture: Confronting the livelihood and environmental realities (pp. 1-10). CABI Publishing.

Scott, C. A., Drechsel, P., Raschid-Sally, L., Bahri, A., Mara, D., Redwood, M., et al. (2009). Wastewater irrigation and health: Challenges and Outlook for mitigating risks in low-income countries. In P. Drechsel, C. A. Scott, L. Raschid-Sally, M. Redwood, \& A. Bahri (Eds.), In: Wastewater irrigation and health: Assessing and mitigating risk in low-income countries (pp. 381-394). Earthscan.

Sengupta, S., Nawaz, T., \& Beaudry, J. (2015). Nitrogen and phosphorus recovery from wastewater. Current Pollution Reports, $1,155-166$.

Shakir, R., Davis, S., Norrving, B., Grisold, W., Carroll, W. M., Feigin, V., \& Hachinski, V. (2016). Revising the ICD: Stroke is a brain disease. Lancet, 19, 2475-2476.

Sharma, N. K., Bhardwaj, S., Srivastava, P. K., Thanki, Y. J., Gadhia, P. K., \& Gadhia, M. (2012). Soil chemical changes resulting from irrigating with petrochemical effluents. International journal of Environmental Science and Technology, 9, 361-370.

Sheet, I., Kabbani, A., \& Holail, H. (2014). Removal of heavy metals using nanostructured graphite oxide, silica nanoparticles and silica/ graphite oxide composite. Energy Procedia, 50, 130-138.

Shen, Y., Oki, T., Kanae, S., Hanasaki, N., Utsumi, N., \& Kiguchi, M. (2014). Projection of future world water resources under SRES scenarios: An integrated assessment. Hydrological Sciences Journal, 59, 1775-1793.

Shuval, H. I., Yekutiel, P., \& Fattal, B. (1985). Epidemiological evidence for helminth and cholera transmission by vegetables irrigated with wastewater. Jerusalem - Case study. Water Science and Technology, 17, 433-442.

Siezen, R. J., \& Galardini, M. (2008). Genomics of biological wastewater treatment. Microbial Biotechnology, 1, 333-340.
Singh, A., Sawant, M., Kamble, S. J., Herlekar, M., Stark1, M., Aymerich, E., et al. (2019). Performance evaluation of a decentralized wastewater treatment system in India. Environmental Science and Pollution, 26, 21172-21188.

Sinha, R. K., Herat, S., Bharambe, G., \& Brahambhatt, A. (2010). Vermistabilization of sewage sludge (biosolids) by earthworms: Converting a potential biohazard destined for land disposal into a pathogen free, nutritive and safe biofertilizer for farms. Waste Management and Research, 28, 872-881.

Smith, R. G. (1995). Water reclamation and reuse. Water Environment Research, 67, 488-495.

Soni, R., Pal, A. K., Tripathi, P., Lal, J. A., Kesari, K., \& Tripathi, V. (2020). An overview of nanoscale materials on the removal of wastewater contaminants. Applied Water Science, 10, 189.

Spina, F., Anastasi, A., Prigione, V., Tigini, V., \& Varese, G. C. (2012). Biological treatment of industrial wastewaters: A fungal approach. Chemical Engineering Transactions, 27, 175-180.

Srivastava, A., Srivastava, O. N., Talapatra, S., Vajtai, R., \& Ajayan, P. M. (2004). Carbon nanotube filters. Nature Materials, 3, 610-614.

SWRCB (2011) Order No. R3-2011-0222: waste discharge requirements NPDES general permit for discharges of highly treated groundwater to surface waters, NPDES NO. CAG993002, California State Water Quality Control Board.

Tacconelli, E., Carrara, E., Savoldi, A., Harbarth, S., Mendelson, M., Monnet, D. L., et al. (2018). Discovery, research, and development of new antibiotics: The WHO priority list of antibiotic-resistant bacteria and tuberculosis. The Lancet Infectious Diseases, 18, 318-327.

Tanji, K. K., \& Kielen, N. C. (2002). Agricultural drainage water management in arid and semi-arid areas. In FAO Irrigation and Drainage Paper (p. 61). Food and Agriculture Organization.

Taylor, A. A., Tsuji, J. S., Garry, M. R., McArdle, M. E., Goodfellow Jr., W. L., Adams, W. J., et al. (2020). Critical review of exposure and effects: Implications for setting regulatory health criteria for ingested copper. Environmental Management, 65, 131-159.

Templeton, M. R., Graham, N., \& Voulvoulis, N. (2009). Emerging chemical contaminants in water and wastewater. Philosophical Transactions of the Royal Society A, 367, 3873-3875.

Toze, S. (1997). Microbial pathogens in wastewater. CSIRO Land and Water Technical report 1/97.

Tringe, S. G., Von-Merling, C., Kobayashi, A., Salamov, A. A., Chen, K., \& Chang, H. W. (2005). Comparative metagenomics of microbial communities. Science, 308, 554-557.

Tripathi, V., Tripathi, P. (2017). Antibiotic resistance genes: An emerging environmental pollutant. K.K. Kesari (ed.), Perspectives in Environmental Toxicology, 183-201.

Tsagarakis, K. P., Tsoumanis, P., Chartzoulakis, K., \& Angelakis, A. N. (2001). Water resources status including wastewater treatment and reuse in Greece. Water International, 26, 252-258.

Tytła, M. (2019). Assessment of heavy metal pollution and potential ecological risk in sewage sludge from municipal wastewater treatment plant located in the most industrialized region 
in Poland-Case study. International Journal of Environmental Research and Public Health, 16, 2430.

Ungureanu, N., Vlăduţ, V., Dincă, M., Zăbavă, B. Ş. (2018). Reuse of wastewater for irrigation, a sustainable practice in arid and semi-arid regions. In Proceedings of the 7 th International Conference on Thermal Equipment, Renewable Energy and Rural Development (TE-RE-RD), Drobeta-Turnu Severin, Romania, 31 May-2 June. pp. 379-384.

Ungureanu, N., Vlăduţ, V., \& Voicu, G. (2020). Water Scarcity and wastewater reuse in crop irrigation. Sustainability, 12(21), 9055.

Upadhyay, K., \& Srivastava, J. K. (2005). Application of ozone in the treatment of industrial and municipal wastewater. Journal of Industrial Pollution Control, 21, 235-245.

US EPA. (2004). Guidelines for Water Reuse 625/R-04/108. Environmental Protection Agency.

US EPA. (2012). Guidelines for Water Reuse 600/R-12/618. Environmental Protection Agency.

Vélez, E., Campillo, G. E., Morales, G., Hincapié, C., Osorio, J., Arnache, O., et al. (2016). Mercury removal in wastewater by iron oxide nanoparticles. Journal of Physics: Conference Series, 687, 012050.

Vergili, I. (2013). Application of nanofiltration for the removal of carbamazepine, diclofenac and ibuprofen from drinking water sources. Journal of Environmental Management, 127, $177-187$.

Vogelmann, E. S., Awe, G. O., \& Prevedello, J. (2016). Selection of plant species used in wastewater treatment. In Wastewater treatment and reuse for metropolitan regions and small cities in developing countries (pp. 1-10). Publisher.

Volesky, B. (1994). Advances in biosorption of metals: Selection of biomass types. FEMS Microbiology Reviews (Amsterdam), 14, 291-302.

Von-Sperling, M., \& Chernicharo, C. A. L. (2005). Biological Wastewater treatment in warm climate regions (1st ed.p. 810). IWA Publishing.

Wani, A. L., Ara, A., \& Usmani, J. A. (2015). Lead toxicity: a review. Interdisciplinary Toxicology, 8, 55-64.

Webster, G. M. (2010). Chemicals, Health and Pregnancy Study (CHirP). Vancouver, BC: University of British Columbia, Centre for Health and Environment Research (CHER) and School for Occupational and Environmental Hygiene (SOEH). http://www.ncceh.ca/sites/default/files/Health_ effects_PFCs_Oct_2010.pdf. Accessed Sept 2019.

Westcot, D. W. (1997). Quality control of wastewater for irrigated crop production. In In Chapter 2 - Health risks associated with wastewater use FAO Water Report (10th ed., p. 86).

WHO (1973) WHO meeting of experts on the reuse of effluents: Methods of wastewater treatment and health safeguards \& World Health Organization. Reuse of effluents: Methods of wastewater treatment and health safeguards, report of a WHO meeting of experts [meeting held in Geneva from 30 November to 6 December 1971].

WHO. (1989) Health guidelines for the use of wastewater in agriculture and aquaculture. Technical Report Series No. 74. World Health Organization, Geneva.

WHO (2003).Copper in drinking-water. Background document for preparation of WHO Guidelines for drinking-water quality. Geneva, World Health Organization (WHO/SDE/WSH/ 03.04/88).
WHO-World Health Organization. (2006). Guidelines for the Safe Use of Wastewater, Excreta and Greywater. In Wastewater Use in Agriculture (2nd ed.). WHO-World Health Organization.

Winpenny, J., Heinz, I., Koo-Oshima, S., Salgot, M., Collado, J., Hernandex, F., et al. (2010). The Wealth of waste: The economics of wastewater use in agriculture. In Food and Agriculture Organization of the United Nations (p. 35). FAO Water Reports.

World Bank. (2010). Improving wastewater use in agriculture: An emerging priority (p. 169). A report of the Water Partnership Program.

World Resources Institute (WRI), (2020) Aqueduct country rankings. Available online: https://www.wri. org/applications/aqueduct/country-rankings/ Accessed 3 Sept 2020.

Xiao, R., Wang, S., Li, R., Wang, J. J., \& Zhang, Z. (2017). Ecotoxicology and environmental safety soil heavy metal contamination and health risks associated with artisanal gold mining in Tongguan, Shaanxi, China. Ecotoxicology and Environmental Safety, 141, 17-24.

Xu, Y. B., Hou, M., Li, Y. F., Huang, L., Ruan, J. J., Zheng, L., et al. (2017). Distribution of tetracycline resistance genes and AmpC $\beta$-lactamase genes in representative non-urban sewage plants and correlations with treatment processes and heavy metals. Chemosphere, 170, 274-281.

Xu, S., Yan, N., Cui, M., \& Liu, H. (2020). Decomplexation of $\mathrm{Cu}(\mathrm{II}) / \mathrm{Ni}(\mathrm{II})-\mathrm{EDTA}$ by ozone-oxidation process. Environmental Science and Pollution Research, 27, 812-822.

Yadav, R. K., Goyal, B., Sharma, R. K., Dubey, S. K., \& Minhas, P. S. (2002). Post-irrigation impact of domestic sewage effluent on composition of soils, crops and ground water-A case study. Environment International, 28, 481-486.

Yang, J., Jia, R., Gao, Y., Wang, W., \& Cao, P. (2017). The reliability evaluation of reclaimed water reused in power plant project. IOP Conference Series: Earth and Environmental Science, 100, 012189.

Yaqub, A., Ajab, H., Isa, M. H., Jusoh, H., Junaid, M., \& Farooq, R. (2012). Effect of ultrasound and electrode material on electrochemical treatment of industrial wastewater. Journal of New Materials for Electrochemical Systems, 15, 289-292.

Yuen, H. W., \& Becker, W. (2020). Iron toxicity. [Updated 2020 Jun 30]. In: StatPearls [Internet]. StatPearls Publishing; Available from: https://www.ncbi.nlm.nih. gov/books/NBK459224/.

Zahmatkesh, M., Spanjers, H., Jules, B., \& Lier, V. (2018). A novel approach for application of white rot fungi in wastewater treatment under non-sterile conditions: Immobilization of fungi on sorghum. Environmental Technology, 39(16), 2030-2040.

Zaman, S. B., Hussain, M. A., Nye, R., Mehta, V., Mamun, K. T., \& Hossain, N. (2017). A review on antibiotic resistance: Alarm bells are ringing. Cureus, 9, e1403.

Zamora, S., Marín-Muñíz, J. L., Nakase-Rodríguez, C., Fernández-Lambert, G., \& Sandoval, L. (2019). Wastewater treatment by constructed wetland eco-technology: Influence of mineral and plastic materials as filter media and tropical ornamental plants. Water, 11, 2344. 
Zekić, E., Vuković, Z., \& Halkijević, I. (2018). Application of nanotechnology in wastewater treatment. GRAĐEVINAR, 70, 315-323.

Zhang, H., \& Reynolds, M. (2019). Cadmium exposure in living organisms: A short review. Science of the Total Environment, 678, 761-767.

Zhang, Y., \& Shen, Y. (2017). Wastewater irrigation: Past, present, and future. Wastewater treatment: Aims and challenges. Water, 6(3), e1234. https://doi.org/10.1002/wat2.1234.

Zhou, X., \& Wang, G. (2010). Nutrient concentration variations during Oenantheja vanica growth and decay in the ecological floating bed system. Journal of Environmental Sciences (China), 22, 1710-1717.
Zhu, L., Li, Z., \& Ketola, T. (2011). Biomass accumulations and nutrient uptake of plants cultivated on artificial floating beds in China's rural area. Ecological Engineering, 37, 14601466.

Zimmels, Y., Kirzhner, F., \& Roitman, S. (2004). Use of naturally growing aquatic plants for wastewater purification. Water Environmental Research, 76, 220.

Publisher's Note Springer Nature remains neutral with regard to jurisdictional claims in published maps and institutional affiliations. 